\title{
Teaching Practices and Social Capital
}

\section{Citation}

Algan, Yann, Pierre Cahuc, and Andrei Shleifer. 2013. Teaching practices and social capital. American Economic Journal: Applied Economics 5(3): 189-210.

\section{Published Version}

doi:10.1257/app.5.3.189

\section{Permanent link}

http://nrs.harvard.edu/urn-3:HUL.InstRepos:11878804

\section{Terms of Use}

This article was downloaded from Harvard University's DASH repository, and is made available under the terms and conditions applicable to Open Access Policy Articles, as set forth at http:// nrs.harvard.edu/urn-3:HUL.InstRepos:dash.current.terms-of-use\#OAP

\section{Share Your Story}

The Harvard community has made this article openly available.

Please share how this access benefits you. Submit a story.

\section{Accessibility}




\title{
Teaching Practices and Social Capital
}

\author{
Yann Algan (Sciences Po) Pierre Cahuc (Ecole Polytechnique) \\ Andrei Shleifer (Harvard University)
}

November 8th, 2010

\begin{abstract}
We use several data sources to consider the effect of teaching practices on student beliefs, as well as on organization of firms and institutions. In individual-level data, teaching practices (such as copying from the board versus working on projects together) exert a substantial influence on student beliefs about cooperation both with each other and with teachers. In cross-country data, teaching practices shape both beliefs and institutional outcomes. The relationship between teaching practices and student test performance is nonlinear. The evidence suggests that schools, and not just families, serve to perpetuate social capital.
\end{abstract}




\section{Introduction}

Since the path-breaking work of Banfield (1958), Coleman (1990), and Putnam (1993, 2000), social scientists have argued that social capital, defined broadly as the capacity of people in a community to cooperate with others outside their family, is an important determinant of various social outcomes. The list of such outcomes includes the provision of public goods (Putman 1993), economic growth (Knack and Keefer 1997, Algan and Cahuc 2010), formation of large firms and organizations (La Porta et al 1997), financial development (Guiso et al, 2004), trade (Guiso et al 2009), as well as methods of state intervention (Djankov et al. 2003, Aghion et al. 2010). Many social scientists have also argued that social capital is highly persistent over time (Putnam 1993, Guiso, Sapienza, and Zingales 2007), largely because the underlying beliefs regarding the benefits of trust and cooperation are transmitted in communities through families (e.g., Bisin and Verdier 2001, Tabellini 2008, Guiso, Sapienza, and Zingales, 2008)or social interactions (Benabou and Tirole, 2010).

In this paper, we explore an alternative, and complementary, mechanism of how social capital is transmitted in a community, namely schooling. Although it is recognized by some authors, such as Aghion et al. (2010) and Guiso et al. (2010), that schooling might be an important mechanism for transmitting social capital, we have not seen any empirical work pursuing this idea. The idea that schooling shapes individual beliefs is of course not new, although in social sciences it is often emphasized by the political left (Bourdieu and Passeron 1970, Bowles and Gintis 1976). Research usually focuses on the level of education rather than teaching practices (Helliwel and Putnam, 2007).

Our starting observation is that the methods of teaching differ tremendously across countries, and between schools within a country. Some schools emphasize what we call vertical teaching methods, whereby teachers primarily lecture, students take notes or read textbooks, and teachers ask students questions. The central relationship in the classroom is between the teacher and the student. Other schools emphasize what we call horizontal teaching methods, whereby students work in groups, do projects together, and ask teachers questions. The central relationship in the classroom is among students. Consistent with the idea that beliefs underlying social capital are acquired through the practice of cooperation, we hypothesize that horizontal teaching methods are conducive to the formation of social capital, whereas vertical teaching methods are not.

To pursue our study, we collect data on teaching methods across schools from several international data sources. The three data bases we examine are 1) the Civic Education Study (CES), run in 1999 in 23 countries to assess the level of civic knowledge of mostly 14 year olds in the $8^{\text {th }}$ and $9^{\text {th }}$ grades, 2) the Trends in International Mathematics and Science Study (TIMSS), conducted in 1995 in 33 countries and focused similarly on the $8^{\text {th }}$ graders, and 3) the Program for International Student 
Assessment (PISA), which we use for 2000 and 2003 waves for 15 year olds in 36 countries. The CES data in particular contains a great deal of student-specific information about student beliefs and characteristics, as well as characteristics of their teachers and their schools, including most importantly teaching methods. In our empirical work, we emphasize the distinction between "students copying from the board" and "students working in groups" as measures of vertical and horizontal teaching methods. We can then use CES at the student and school level to relate teaching methods to student beliefs, and use all data sources at the country level to relate teaching methods to a variety of measures of both beliefs and social outcomes.

In doing so, we seek to address four questions. First, do teaching methods vary systematically across countries? The answer to this question is a clear yes. Second, do teaching methods matter for student beliefs? The answer is again a clear yes. There are very strong correlations between teaching methods and student beliefs both in a cross-section of countries, and more importantly, in a cross-section of students in the CES sample, holding country fixed effects, as well as a variety of student, school, and teacher characteristics constant.

Third, do the differences in teaching methods only reflect the differences in the beliefs or preferences of the community or do they perhaps also have an independent component that shapes student beliefs? If teaching methods entirely reflect community preferences, then one might still argue that families shape beliefs, and schools merely reinforce what families teach kids already. If teaching methods have an independent component, there is a possibility that schools can build social capital even in communities where parents lack it. This question is obviously very difficult to answer. We try to address it in student-level regressions by first controlling for teachers' social capital, on the assumption that teacher beliefs capture community preferences. We find that, even holding teacher beliefs constant, teaching practices exert a large influence on student beliefs, which provides some evidence for the hypothesis that schools may matter beyond families. We also run our regressions on the subsample of students born abroad, on the theory that social capital of their parents is uncorrelated with teaching practices in the school they attend. We find that even for immigrant children, teaching practices substantially influence beliefs.

Having established the strong relationship between teaching practices and student beliefs, we turn to the cross-country evidence and ask whether teaching practices are related to a broader set of beliefs and social outcomes. In all cross-country specifications, we control for per capita income and average years of education, but the issue of omitted variables still looms large here.

We find a variety of interesting correlations. In terms of beliefs, students in countries with vertical teaching methods display lower assessment of the value of cooperation with other students 
and a lower assessment of teacher fairness and willingness to listen than do students in countries with horizontal teaching methods. Vertical teaching is also associated with greater belief (from the WVS) that it is the duty of children to respect their parents. Interestingly, vertical teaching methods are associated with students feeling "like an outsider" and "awkward and out of place" in the classroom (from PISA). Vertical teaching methods are also highly negatively correlated with trust and association membership, the two standard measures of beliefs underlying social capital from the WVS. Finally, vertical teaching methods are associated with lower trust in civil servants and lower level of belief that civil servants treat citizens fairly (both measures from the International Social Survey Program). It appears that subordination to teachers as a student leads to a feeling - and perhaps a reality -- of subordination to bureaucrats as an adult.

With respect to "real outcomes" as opposed to just beliefs, we looked at two aspects of organization of firms, an area that some studies argue is related to social capital (La Porta et al. 1997, Bloom et al. 2007). We find that vertical teaching methods are associated with lower assessed incidence of delegation of authority in firms (Global Competitiveness Report) and lower perceived freedom of daily work organization (European Social Survey). Again, teaching practices appear to translate into work practices, suggesting that social skills learned in school are used later. We also find that vertical teaching methods are strongly related to a perception of inferior labor relations. Perceived unfairness of teachers may lead to that of bosses.

We also look at two measures of institutional quality: the (subjective) government effectiveness index from Kauffman et al. (2008) and the objective measure of entry regulation from Djankov et al. (2002). In an earlier paper (Aghion et al. 2010), we argued that low levels of social capital lead people to demand government regulation, even if they perceive government officials to be corrupt, largely because they distrust businesses more. On that theory, vertical teaching methods, in so far as they build low levels of social capital, should be associated with lower government effectiveness and higher entry regulations. We find that this is indeed true in the data.

As a final step in the analysis, we ask whether educational quality might be compromised by teaching practices favorable to the formation of social capital. We find that extreme bias toward some teaching practices is detrimental to test scores, and that some mixture of horizontal and vertical teaching practices supports best academic performance.

In the next section, we describe our data sources and measures of teaching methods. Section 3 then presents the micro evidence on the relationship between teaching methods and student beliefs. Section 4 looks at the macro correlations. In Section 5, we consider student test scores. Section 6 concludes. 


\section{International comparison on teaching practices}

This section presents the data on teaching practices across countries. We show that countries differ a lot in their reliance on what we call vertical and horizontal teaching practices.

\subsection{Database}

We combine three main international databases to analyze country differences in teaching practices. The first database is the "Civic Education Study" (CES), based on a survey run in 1999 by the International Association for the Evaluation of Educational Achievement (IEA). The CES is designed to assess the civic knowledge of students in grades 8 and 9 in 23 countries. The study covers Australia, Bulgaria, Colombia, Cyprus, Czech Republic, Denmark, England, Estonia, Finland, Germany, Greece, Hungary, Italy, Latvia, Lithuania, Norway, Portugal, Romania, Russian Federation, Slovak Republic, Slovenia, Sweden, Switzerland, United States. The sample covers 140,000 students, 9,000 teachers and 4,000 school principals. The assessment is designed to measure various dimensions of civic knowledge, including concepts of democracy and citizenship, attitudes to institutions, trust and civic-related actions, as well as beliefs about cooperation among students and cooperation between students and teachers. In addition to the individual student survey, the CES includes school-principal and teacher background questionnaires. Critically, the teacher questionnaire requests detailed information on teaching practices of the teachers. Each of the participating countries randomly samples the students to be surveyed using a two-stage stratified sampling design. The primary sampling unit (PSU) is the schools randomly selected in each country. The students from grade 8 (or 9) are then randomly picked from the assigned class in the selected school. The teachers of those selected students completed individual surveys (as did school principals). For students with multiple teachers (up to a maximum of five in the database), all the teachers completed the questionnaire.

The individual teacher surveys asked the following questions about teaching practices: « In your class, a) How often do students work in groups? b) How often do students work on projects ? c) How often do students study textbooks? , d) How often do students participate in role play, e) How often does the teacher lecture? , f) How often does the teacher include discussions, g) How often does the teacher asks questions? ". The answers take on values 1 for Never, 2 for Sometimes, 3 for Often and 4 for Very Often.

The second international database is the Trends in International Mathematics and Science Study (TIMSS). The TIMSS is a cross-country comparative test of student cognitive achievement in math and science, conducted in 1995 by the IEA, the same international consortium that constructed 
the CES database. TIMSS is also targeted to students belonging to grade $8^{\text {th }}$ and cover 33 countries: Australia, Austria, Belgium, Bulgaria, Canada, Czech Republic, Denmark, Finland, France, Germany, Greece, Hungary, Iceland, Indonesia, Iran, Ireland, Israel, Italy, Japan, Korea, Latvia, Lithuania, Netherlands, Norway, Portugal, Romania, Russia, Singapore, Slovakia, Slovenia, Spain, Sweden, Switzerland, Turkey, United Kingdom and United States. The database combines information from student, school-principal, and teacher questionnaires for representative sample of students.

Unlike the CES, the TIMSS database does not have specific questions on student beliefs, since the primary focus of this study is the assessment of cognitive performance. However, the student questionnaire does ask specific questions about teaching practices for a larger and more diverse group of countries than the CES. Teaching practices are measured from the individual student surveys conducted in all classrooms in each selected school. The survey covers the classes in mathematics, science, biology, chemistry and earth science. We focus on teaching practices in mathematics, which allow observations for the maximum number of countries. The appendix reports results for practices in other classes, which turn out to be highly correlated within each country. The questions on teacher practices most related to our analysis are: "In schools, how often do you do these things? Copy notes from the board during the lessons? , Work together in pairs and small groups in class?" The answers range from 1 for All the time, 2 for Often, 3 for Sometimes to 4 for Never. We reverse the order of the answers to get a scale comparable to that of the CES. The higher is the value of the TIMSS indicator, the more frequent is the teaching practice.

\subsection{Vertical versus Horizontal Teaching}

Figure 1 presents the correlation between the indicators "Students work in group" and "Teacher lectures" taken from the CES at the country-level. The higher is the value of the indexes "Students work in group" and "Teacher lectures", the more frequent are these teaching practices. Figure 1 shows a negative cross-country correlation between these two practices, with the coefficient of correlation equal to -0.418 . The share of teachers who frequently ask their students to work in groups is higher in Nordic countries (Denmark, Norway, Sweden) and Anglo-Saxon countries (Australia, United States and to a lesser extent Great Britain). This teaching practice is less common in East European countries and the Mediterranean (Greece, Cyprus, Portugal and, to a lesser extent, Italy). In contrast, East European and Mediterranean countries display a higher share of teachers reporting that they lecture most of the time. Figure 1 also suggest that in countries such as Germany and Switzerland teachers combine the two practices, or do something else with their class time.

To get a more comprehensive picture of the different patterns across the various teaching 
practices, we run a factor analysis on the six practices reported in the CES database. Table 1a documents the correlation between the different teaching practices. Table $1 \mathrm{~b}$ shows the factor analysis that leads us to select two mains factors for clustering the teaching practices. We call the first factor Vertical Teaching, to capture situations in which teachers tend to lecture, ask the students questions, and ask the students to work alone on their textbook. We call the second factor Horizontal Teaching, to capture situations in which the teacher tends to ask students to work in groups, work on projects, participate in events and role play, and have discussions. Together, these two factors explain 82 percent of the cross-country variance in teaching practices.

Figure 2 shows the cross-country relationship between the indicators of Vertical Teaching and Horizontal Teaching from the CES database. Vertical Teaching is measured by the first principal component of the practices "Teacher lectures", "Teachers ask questions", and "Teachers ask students to work alone on their textbook". Horizontal Teaching is the first principal component of the practices "Students work in groups", "Students work on projects", "Students work in plays", "Teacher discusses with students" and "Students participate in events". Figure 2 shows a steep negative correlation between Vertical Teaching and Horizontal Teaching, with the coefficient of correlation of -.648. Figure 2 displays clearer clusters of different teaching practices. Nordic and Anglo-Saxon countries emphasize horizontal teaching practices, while Mediterranean and East European countries favor vertical teaching. Continental European countries fall in the middle.

Figure 3 shows the teaching practices based on the TIMSS database. We report the correlation between the frequencies of taking notes from the board and of working in groups at the country level. The variables range from 1 to 4 , a higher score indicating a higher frequency. The cross-country correlation is -0.137 . The figure suggests that, in all countries, students take notes from the board more frequently than they work in groups. In addition, some countries seem to combine the two practices, or to do something else with their class time. This might explain the low negative correlation between the original indexes. To differentiate the teaching practices across countries, it might help to measure the extent to which a country tilts towards vertical rather than horizontal teaching. We measure this tilt with two indices. The first is the difference between the original indexes "Take notes from the board" and "Work in group". The second index is equal to the share of students who report that they always take notes from the board. Figure 4 presents these two indexes. The y-axis measures the difference between the variable "Take notes from the board" and "Work in Group". The x-axis measures the share of students who say they always take notes from the board. The clustering of countries along these two new teaching practices indexes is stark. Nordic countries (Denmark, Sweden, Norway, Netherlands) and Anglo-Saxon countries exhibit a low 
gap between the practices of working in groups and taking notes from the board. The share of students who report that they always take notes from the board is also fairly low in this case: 10.4 percent in Sweden, 13.1 percent in Denmark, 22.3 percent in Great Britain or 26.3 percent in Canada. At the other extreme is a second group of countries in which teachers ask their students to take notes from the board much more frequently than to work in groups. The gap is particularly high in Japan, France, Mediterranean countries, and East European countries. In this group of countries, the majority of students also report that they always take notes from the board, with a peak of 74.2 percent in Japan, 64.3 percent in Turkey, 55.8 percent in France.

Table $1 \mathrm{c}$ reports the correlation between the different indicators of teaching practices at the country level. In particular, we check the consistency of the practices as reported in the CES and the TIMSS databases. The phrasing of the questions differs between the two surveys, but they capture the same broad contrast between vertical and horizontal teaching. This comparison also sheds light on whether the students and teachers share the same perceptions about teaching practices, since the questions are administrated at the teacher level in the CES and at the student individual level in the TIMSS. Table 1c confirms the high correlation between these indicators across the surveys.

Figure 1 - Cross-country correlation in teaching practices: Teacher Lectures versus Students Work in Groups -(1=Never, 2=Sometime, 3=Often, 4=Always). Source: CES

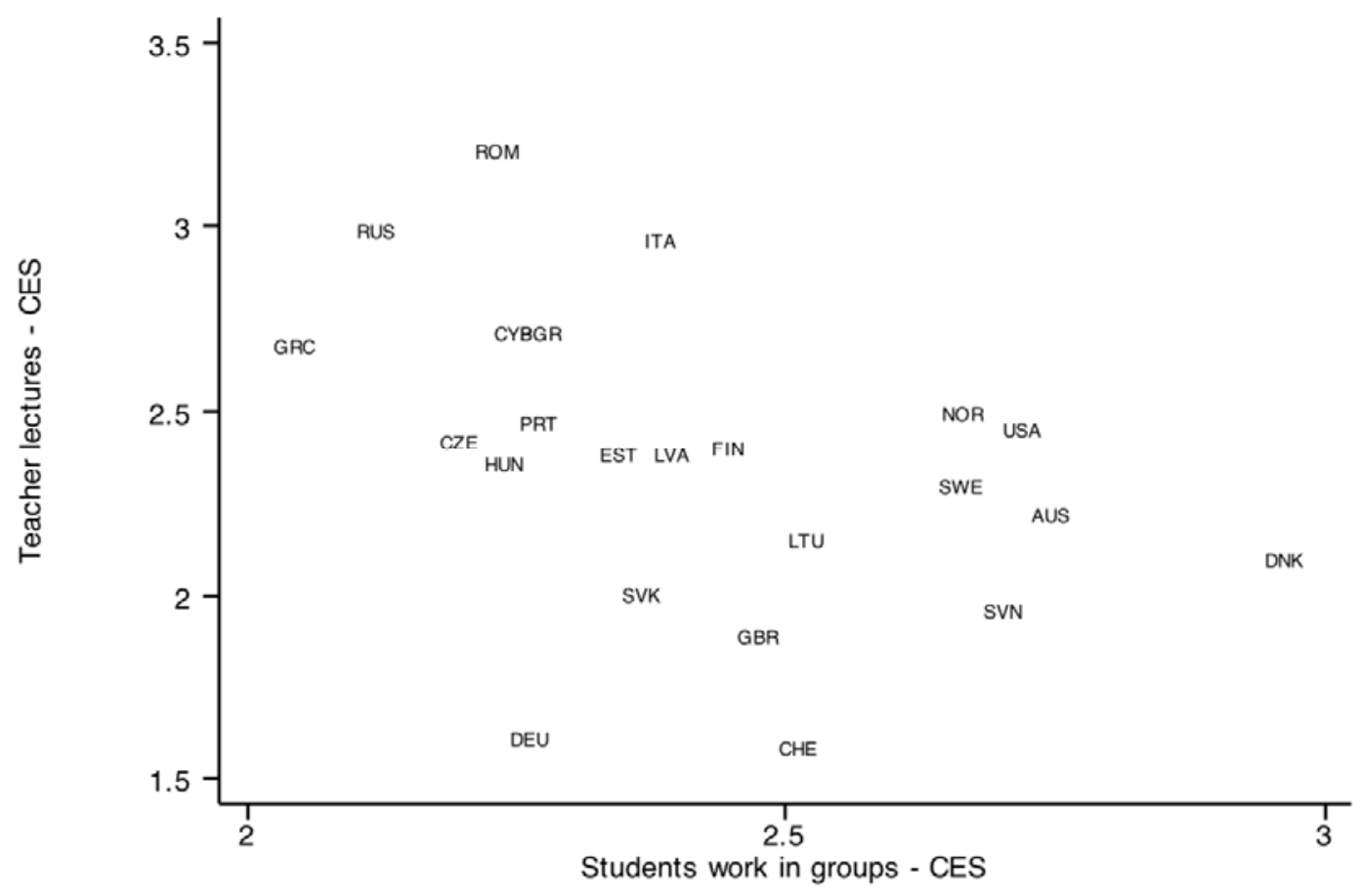


Figure 2 - Cross-country correlation in teaching practices: Principal components for Vertical Teaching versus Horizontal Teaching - Source CES

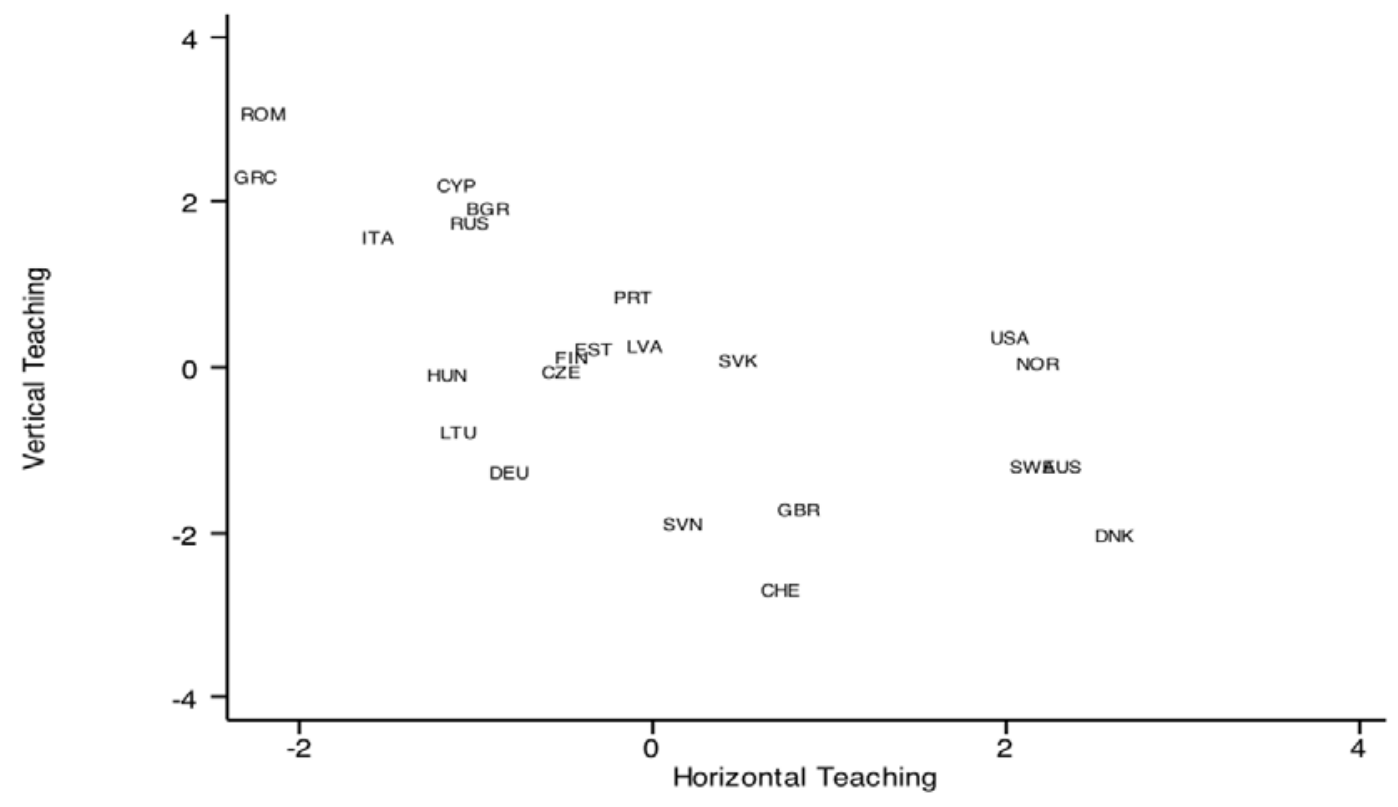

Figure 3 - Cross-country correlation in teaching practices from TIMSS: country-level score for the questions "Student take notes from the board" and "Students work in groups" (1=Never, 2=Sometime, 3=Often, 4=Always)

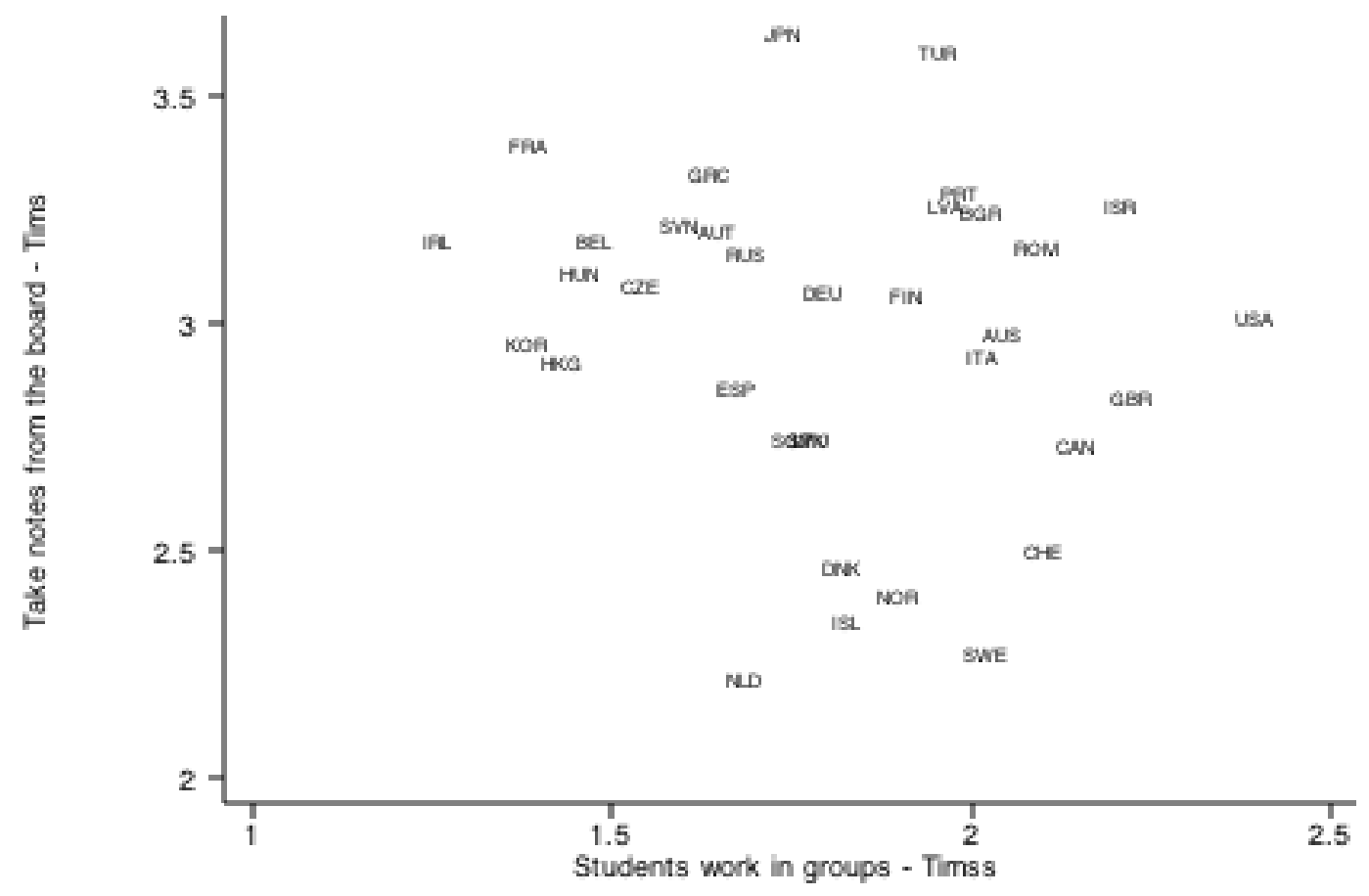


Figure 4-Gap between the answers to "Students take notes from the board" and "Students work in groups", and the country share of students who answer "Always take notes from the board" (TIMSS)

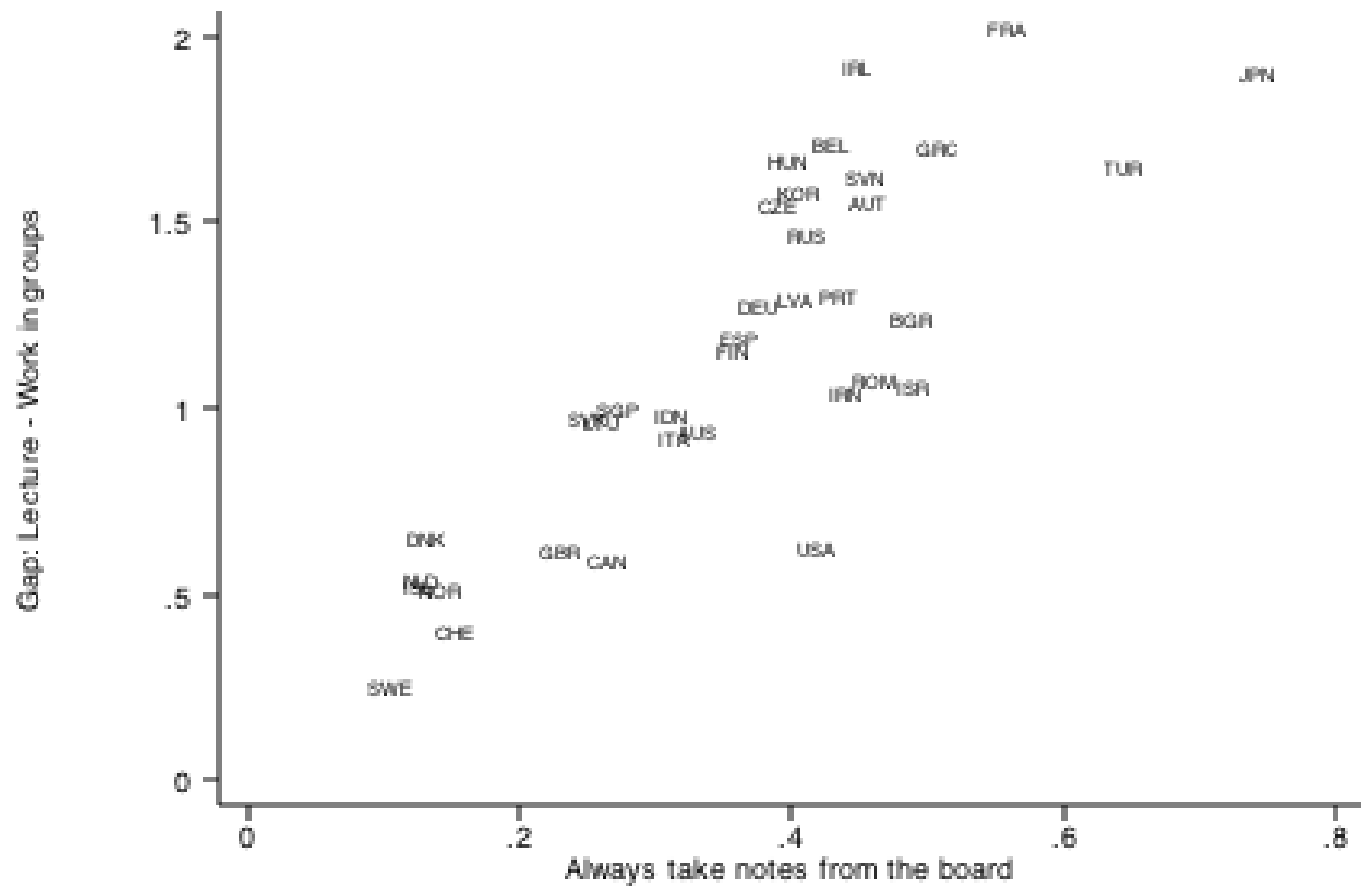

\section{Teaching practices and Student Beliefs: Micro Evidence}

This section investigates the relationship between teaching practices and individual student beliefs about cooperation. We use the CES database that asks students detailed questions about their beliefs, and then asks these students' teachers questions about their teaching practices. We start with the micro evidence to see how far we can go to isolate the effect of teaching practices per se, as opposed to merely showing the correlation between parental beliefs in a school as expressed in that school's teaching practices and student beliefs.

\subsection{Database and specifications}

The main explanatory variables of interest are the teaching practices reported in the teacher survey described in Section 2. We focus first on two CES indicators "Teacher Lectures" and "Students work in groups". We also use more comprehensive indicators of "Vertical Teaching" and "Horizontal Teaching" from the principal component analysis described in Section 2.

In addition to teaching practices, we control for many background factors from student, principal, and teacher questionnaires that are traditionally included in cross-country estimates of the 
education production function (see Woessman (2005) for an analysis based on TIMSS, and Hanushek and Woessmann (2010) for a synthesis).

At the student level, the basic characteristics include age, gender and immigration status (dummy equal 1 if the student is born abroad and 0 otherwise). We control for the socio-economic background of the parents by including their level of education. The parental education variable is equal 1 for No elementary school, 2 for Completed elementary school, 3 for High School, 4 for Completed High School, 4 Higher technical education, 5 for Some college - university degree, and 6 for Graduate degree. We also use student responses on the number of books at home, equal 1 for None, 2 for One-Ten books, 3 for Eleven-Fifty Books, 4 for Fifty one- One hundred books, 5 for Onehundred and one-Two hundreds books, and 6 for More than two hundred books. This variable has been found to be a more cross-country comparable measure of family background than parental education, and to be the single most important predictor of student performance in most countries (Hanushek and Woesmann, 2010). Schuetz et al (2008) show that the number of books at home is a very good proxy for household income, a variable that is not reported in the CES dataset.

At the teacher level, we include the teacher's age, gender, highest level of formal education, and years of experience. We also use questions about teachers' beliefs in cooperation and proxies for their social capital. These measures make it possible to identify the specific role of teaching practices on students' beliefs, independently of alternative ways through which teachers could transmit their social capital and shape students' beliefs. Furthermore, if there is a low geographic mobility of teachers, their level of social capital might be considered as a proxy for the local level social capital in the area where students live. We use this information as an additional control to isolate the specific role of teaching practices on student beliefs, which roughly holds constant social capital in the geographic location, and thus, perhaps, in the family.

We measure teachers' beliefs about cooperation using the following questions they answer: "Students learn at school to understand people" and "Students learn at school to cooperate in groups". The answers range from 1 for "Strongly disagree" to 4 for "Strongly agree". We take the first principal component of answers to these questions to create a synthetic indicator of "Teacher's belief in cooperation". We measure teachers' civic attitudes using a set of questions on what they consider important for being a good citizen. The questions read: "For being a good citizen, one has to vote on every election", "For being a good citizen, one has to join a political party", "For being a good citizen, one has to read about politics", "For being a good citizen, one has to participate in social activities". The answers range from 1 for "Strongly disagree" to 4 for "Strongly agree". We create a synthetic indicator of "Teacher's civic attitude" by taking the principal component of answers to 
these questions. We also measure teachers' level of trust in institutions using the questions: "How much confidence do you have in the political system?", "How much confidence do you have in elections?", "How much confidence do you have in the judicial system?", "How much confidence do you have in immigration?", "How much confidence do you have in social welfare?", "How much confidence do you have in labor unions?". The answers equal 1 for "Not at all", 2 for "Little confidence", 3 for "Confident" and 4 for "Very confident". We create an index of "Teacher's trust" by taking the principal component of the answers to these questions. Unfortunately, the teacher questionnaire does not contain questions about generalized trust.

At the school level, the regressions include a measure of school resources, the size of the class being interviewed, and the number of students with low socio-economic backgrounds. From the school principal's questionnaire, we also code whether the school is public or private.

We run cross-country micro-estimates at the student level, with robust standard errors clustered at the school level. For students who have multiple teachers, we consider the average characteristics of the teachers as independent variables. The results are not markedly different when we consider as separate observations the teaching practices of each teacher for each student, since there is very few variations in teaching practices within schools in the database. The relationship between student beliefs and teaching practices is not statistically significant, however, when we run the estimates with school fixed effects, i.e., when we look at the role of variation in teaching practices within school.

We identify the relationships between teaching practices and student beliefs within countries by including country-fixed effects in all the regressions. We thus exploit the variation in teaching practices across schools, making it possible to disentangle the specific role of teaching practices on students' beliefs from other national characteristics such as social capital or institutions. All standard errors are clustered at the school level. Since the CES dataset uses a stratified sampling design, all estimations are weighted by the sampling probabilities.

\subsection{Results}

We first estimate the relationships between student beliefs about cooperation among themselves and teaching practices. From the student survey, we use the following two questions: "The goal of education is to understand people with different ideas" and "The goal of education is to learn how to cooperate in groups with other students". The answers ranges from 1 for Strongly Disagree, 2 for Disagree, 3 for Agree and 4 for Strongly Agree. We create a synthetic indicator of "Belief in cooperation between students" as the principal component of answers to these questions. 
The OLS results on student beliefs in cooperation with other students are reported in Table 2. Column 1 shows that such beliefs are negatively related to "Teacher lectures", with the coefficient statistically significant at the 1 percent level. In contrast, the belief in cooperation among students is positively associated with "Students work in group." The coefficient is positive and statistically significant at the 10 percent level. Columns 3 and 4 confirm these findings by showing a negative relationship between beliefs in cooperation and "Vertical Teaching", and a positive relationship with "Horizontal Teaching." The associated coefficients are statistically significant at the 5 percent level. The only other teacher characteristics that seem to matter are teacher civic attitudes and, to a lesser extent, teacher experience. Similarly, there is no systematic relationship between student belief in cooperation and any other school-level characteristic, except the (In)-size of the classroom.

To give a sense of the magnitude of the effects, we estimate the regressions separately for the original questions about student beliefs instead of taking their principal component. All the right hand side variables are identical to those used in Table 2 . We comment on the coefficients without reporting the full tables. Consider the results for the question: "The goal of education is to understand people with different ideas". The left hand side variable is equal 1 if the student agrees or strongly agrees with this statement, and 0 if he disagrees or strongly disagrees. In this case, the probability that the student agrees with this goal of education is 1.86 percentage points higher if the teachers ask the student to work in a group often or very often (instead of never or sometime). In contrast, this probability is 1.96 percentage points lower if the teachers lecture often or very often. These effects might appear relatively modest, but are substantial compared to the other characteristics. The single other teacher or school characteristic that is statistically significant at that level is the size of the classroom, but it has a tiny effect. One would need to reduce the size of the class by up to twelve students to get an effect on student's beliefs comparable to asking them to work in groups. Second, the single individual characteristic that has a more sizeable effect than the teaching practices is gender; its effect is three times as high as that of teaching methods. This result is in line with Croson and Gneezy's (2009) finding of important gender differences in the context of experimental public good games. The results are similar for the other question:"The goal of education is to learn how to cooperate in groups with other students".

The second dimension of student social capital is belief in cooperation with their teachers. We use the following related questions from the student questionnaire: "Are students encouraged to make up their own opinion?" "Do teacher respect your opinion?", " Do you feel free to express opinions in class?", "Do you feel free to openly disagree with the teacher?". The answers range from 1 for strongly disagree to 4 for strongly agree. We take the principal component of answers to these three questions to create the synthetic indicator of "Cooperation with Teachers". 
Table 3 - Column 1 shows a strong negative relationship between student beliefs in cooperation with teachers and teachers spending most of their time lecturing. The effect is statistically significant at the 1 percent level. Column 3 shows that the indicator of vertical teaching is negatively related to the belief in cooperation with teachers; the effect is statistically significant at the 5 percent level. Conversely, these beliefs are positively related with teachers asking most of the time for their student to work in groups (Column 2) or with the synthetic index of horizontal teaching practices (Column 4). The association between horizontal teaching practices and student belief in cooperation with teachers is statistically significant at the 1 percent level.

To interpret the magnitude of these effects, we look once again at the original questions rather than using their first principal component. We again comment on the coefficients without reporting the full tables. Consider the results for the question: "Do teachers respect your opinion?". The dependent variable is equal to 1 if the student agrees or strongly agrees with this statement, and to 0 otherwise. All the right hand side variables are identical to those used in Table 3 . Teachers asking the student to work in a group often or very often (instead of never or sometime) is associated with an increase by 2.69 percentage points in the probability of believing that teachers respect the student's opinions. This effect, however modest at first sight, is substantial relative to the other characteristics. First, this teaching practice is statistically significant at the 1 percent level while none of the other variables at the teacher or school level are correlated with the student beliefs in this regression. Second, the coefficient on the variable "Students work in group" is sizeable compared to others. The positive effect of "Students work in groups" is of the same order of magnitude as being three years older, or as an increase by three levels in the variable "Father's education", which is equivalent of having a father with a high school rather than an elementary school degree. The only student characteristic that is more consequential than "Students work in groups" is once again gender. Being a girl raises by 6.66 percentage points the probability of thinking that teachers respect one's opinion, an effect almost two and a half times as important as the variable "Students work in groups". The results are similar if we consider the teaching practice "Teacher lectures" instead of "Students work in groups". "Teacher lectures" often or very often (instead of never or sometime) is associated with a decrease by 1.70 percentage points in the probability of thinking that teachers respect the student's opinions. The effects of the other individual teacher or schools characteristics are similar to those noted earlier. The results are similar for the other questions related to student's beliefs about cooperation with teachers.

The third dimension of students' social capital is their participation to civic life. Table 4 shows the relationship between teaching practices and the involvement of students in associations. The student survey proposes 14 potential organization: "Have you ever participated in: A student 
council? A youth organization? A school newspaper? An environmental organization? A U.N or UNESCO Club? A Student exchange program? A Human Rights Organization? A Group Conducting Activities? A Charity Collecting ? A boy or girl scout group? A cultural association? A computer club? An art, drama or music association? A Sport Organization? An association supported by a religious group?". For each association, the answer is equal to 1 if the respondent participates and to 0 otherwise. We take the principal component of the answers to these questions to get a synthetic measure of Association membership.

Table 4 shows Association membership is negatively associated with the variables "Teacher lectures" and "Vertical Teaching"; the coefficient is statistically significant at the 1 percent level for "Teacher Lectures" (Column 1). In contrast, there is a strong positive relation between association membership and "Students work in groups" and "Horizontal Teaching", the coefficients being significant at the 5 and 1 percent levels, respectively. Association membership is more closely related to horizontal methods of teaching than to vertical ones.

The size of the relationship between teaching practices and association membership is also substantial. To ease the interpretation of the results, we rerun the estimates by considering as the dependent variable the number of associations to which the student belongs, rather than taking the principal component. The total number of associations per student ranges between 0 and 14 . In this case, "Teacher lectures" often or very often is associated with a decrease by 12.3 percentage points in the number of associations to which a student belongs. In contrast, the number of associations is 9.98 percentage points higher when teachers ask the student to "Work in groups." For the sake of comparison, the effect of working in groups is three times as high as the gender, and two and half times as large as the education of the mother. The single other variable at the teacher or school level that is statistically significant is the size of the classroom. It would require reducing by 6.5 students the average size of the class to get the same effect as asking students to work in groups.

Finally, we look at the relationship between teaching practices and trust. From the CES, we use the following questions: "How much confidence do you have in: i) Courts? , ii) The Police?, iii) Education institutions/Schools? , and iv) The people who live in this country ?". We construct a synthetic index for "Trust" as the principal component of answers to these questions. Table 5 shows that the indicator of "Trust" is positively related to horizontal teaching and negatively related to vertical teaching. The coefficient is statistically significant at the 5 percent level in the case of horizontal education. The evidence at the student level thus provides a very consistent picture that horizontal teaching methods raise social capital, and vertical ones reduce it. 
We conclude this section with an alternative attempt to identify the effect of teaching practices on student beliefs. So far, all the regressions control for country-fixed effects, identifying the effects of teaching practices from school differences. This strategy makes it possible to disentangle the role of school from alternative national educational policies or from the national level of social capital. But it still might be the case that the organization of schools reflects, at the local level, the beliefs of the parents or of the local community. In this case, we would be estimating the effect of local social capital rather than of teaching practices on student beliefs. One way to control for this alternative explanation is to include the teacher's social capital as a proxy for the local level of social capital and for alternative ways of transmitting beliefs.

An alternative strategy for identifying the effect of teaching practices it to focus on students born abroad. Indeed, teaching practices are less likely to reflect the beliefs of parents of foreignborn students than those of natives. It is possible that immigrants sort into communities sharing their beliefs, so identification is not perfect. This strikes us as a somewhat remote possibility.

Tables R1 and R2 show the results for the sub-sample of immigrants. All the controls are the same as the ones used in the previous specifications, and robust standard errors are still clustered at the school level. Columns 1 and 2 of Table R1 show that immigrant students' belief in cooperation with teachers is positively correlated with horizontal teaching and negatively correlated with vertical teaching. The relationship is statistically significant at the 1 percent level in the latter case. Columns 3 and 4 show a similar correlation pattern between teaching practices and immigrant students' belief in cooperation among students. In this case, it is horizontal teaching that is statistically significant at the 1 percent level and positively related to student's belief in cooperation among students. Table R2 report the results for Trust and Association membership on the subsample of immigrants. Horizontal teaching is positively correlated with trust, and the relation is statistically significant at the 1 percent level. The results are not statistically significant for association membership. These results are based on a smaller sample, and are not as uniform as those for the sample as a whole, yet overall they appear to confirm previous findings on the specific role of teaching practices in shaping students' social capital.

\section{Teaching practices and Aggregate outcomes}

Turning to the aggregate implications of teaching practices for social capital, we assess crosscountry relationships between teaching practices measured at the country level and various social outcomes, including trust and civic life, but also the organization of firms and institutions. 
In line with the micro-estimates, we focus on the distinction between vertical and horizontal teaching, captured by the indicators "Students take notes from the board" for the former, and "Students work in groups" for the latter. These indicators are taken from the TIMSS database, which has the advantage of covering more countries than the CES data used in the micro estimates. In addition, TIMSS covers more diverse countries (the CES is mainly centered on European countries). Following our analysis of the TIMSS database in Section 2, we focus first on the difference between the country share of students who report taking notes from the board and that working in groups, and second on the country share of students who report that they always take note form the board. The Appendix results are similar when we focus on the average values of "Students take notes from the board" and "Students work in groups".

The regressions include several controls. The first is the level of education from the Barro and Lee database for 2000. Education has been found to be crucial in explaining various civic outcomes as well as the development of democracy (Lipset 1959, Helliwell and Putnam 2007, Glaeser, Ponzetto and Shleifer, 2007). Another concern is that teaching practices proxy for per capita income. In poor countries, it might be less costly for teachers to lecture than to ask students to work in groups. We control for total annual expenditure per student in public institutions for secondary education, which corresponds to the grades where teaching practices are measured in TIMSS. Total expenditure per student is calculated as a percentage of GDP in US 2002 dollars adjusted for PPP. The data come from UNESCO. An additional control is GDP per capita, expressed in US 2000 dollars. These last two controls are highly correlated.

\subsection{Teaching practices and Students Beliefs in Cooperation}

We first investigate the cross-country relationships between teaching practices and student beliefs in cooperation, similarly to what we did at the individual level in Section 3.

We use a comprehensive set of student attitudes toward cooperation at school from the Program for International Student Assessment (PISA). This survey was run in 2000, 2003 and 2006 by the Organization for Economic Cooperation and Development (OECD). The PISA survey is meant to provide international comparison of cognitive skills of students who are 15 years old, by asking standardized questions in mathematics, science, reading, and problem-solving. Information on the way schools are run is collected through a school principal questionnaire. PISA does not include a teacher survey and, unlike the CES and the TIMSS, does not report teaching practices in detail. But the background student questionnaire provides an indication of student perception of cooperation among students, as well as between students and teachers. These questions are available in the surveys 2000 and 2003 for 29 countries for which we also have observations for our control 
variables: Australia, Austria, Belgium, Czech Republic, Denmark, Finland, France, Germany, Greece, Hungary, Iceland, Indonesia, Ireland, Italy, Japan, Korea, Latvia, Netherlands, Norway, Portugal, Romania, Slovakia, Spain, Sweden, Switzerland, Turkey, United Kingdom and the United States.

\subsubsection{Cooperation between students}

From PISA 2000 and 2003, we use the following questions on attitudes towards cooperation between students: "I enjoy working with other students in group", "When we work on a project, I think that it is a good idea to combine the ideas of all the students in a group", "I do my best work when I work with other students" and "I learn most when I work with other students in my class". The answers range from 1 for Strongly disagree, 2 for disagree, 3 for Agree, and 4 for Strongly agree. We calculate the first principal component of answers to these 4 questions to create a synthetic indicator of "student cooperation" at the country level. A high value of the first principal component indicates strong beliefs in cooperation between students.

Table 6, Columns 1-3 report the OLS cross-country estimates controlling for (In)-school expenditure per student, the (In) income per capita, and average years of education. Column 1 shows a strong negative relationship between "student cooperation" and the country-share of students who never work in groups. The coefficient is statistically significant at the 5 percent level. Column 2 shows a negative association of the same magnitude between "student cooperation" and the country share of students who always take notes from the board. Column 3 reports that the relationship is statistically significant at the 1 percent level when we consider the gap between Vertical Teaching and Horizontal Teaching rather than taking these teaching practices separately. Twenty-one percent of the cross-country variation in beliefs about student cooperation is explained by the gap between Vertical and Horizontal Teaching.

The size of the coefficients is substantial. Teaching practices are the only variables that are statistically significantly related to "student cooperation". Neither school expenditure per student, nor income per capita, nor average years of education are related to student attitudes toward cooperation. To ease the interpretation, we look at the estimates using the original questions rather than the principal component. An increase by one-standard deviation (across countries) in the share of students who always take notes from the board is associated with a decrease by 8 percentage points in the share of students who agree or strongly agree with the statement "I enjoy working with other students in group". An increase by one standard deviation in the share of students who never work in groups is associated with a decrease by 7 percentage points in the share of students who (strongly) agree with the statement: "I learn most when I work with other students in my class". 


\subsubsection{Cooperation with Teachers}

We now turn to the relationship between teaching practices and cooperation between teachers and students. We measure this relationship using student beliefs from PISA. The student questionnaires ask the following questions: "In general teachers treat me fairly", "In general students and teachers get along", "In general the teacher listens to me". The answers range from 1 for Strongly disagree, 2 for Disagree, 3 for Agree and 4 for Strongly agree. We create a synthetic indicator of "cooperation with teachers" by taking the principal component of answers to these three questions. Table 6 shows a strong negative relationship between "cooperation with teachers" and the share of students who never work in groups (Col. 4), who always take notes from the board (Col. 5), or who face an education more tilted toward vertical rather than horizontal teaching practices. The correlations are statistically significant at the 5 or 1 percent level. Nineteen percent of the cross-country variation in "cooperation with teachers" is explained by the gap between vertical and horizontal teaching practices.

We complement this analysis by looking at the relationships between teaching practices and beliefs about family life. From the World Values Surveys 2000, we use the question: "Children should respect their parents regardless of their merits and their faults". The variable equals 1 if the answer is yes, and 0 otherwise. We calculate the country share of positive answers to this question for the countries that are also included in TIMSS and for which we have observations on teaching practices.

Table 7 - Col. 1-3 show that teaching practices are more broadly related to attitudes toward hierarchical relationships between children and parents. In particular, the country share of students who always take notes from the board is positively related to share of individuals agreeing with the statement that children must always respect their parents. The relationship is statistically significant at the 1 percent level, and 45 percent of the cross-country variation in family values is explained by the cross-country variation in this teaching practice.

Table 7 - Col. 4-6 explore the relationship between students' feeling alienation and the teaching practices. From PISA, we take two related questions: "In general, do you feel like an outsider in your class?", "In general, do you feel awkward in your class". The answers range from 1 for Strongly disagree, 2 for Disagree, 3 for Agree to 4 for Strongly agree. We create an indicator for students feeling alienation by taking the first principal component of answers to these two questions, a higher value indicating a stronger feeling of alienation. Table 7 shows that feelings of alienation are positively related to "Always take notes from the board"; the coefficient is statistically significant at 
the 1 percent level. Forty five percent of the cross-country variation in student alienation is explained by the share of students who spend most of their time taking notes from the board. Working in groups is not associated with the indicator of alienation.

\subsection{Teaching practices and Aggregate Social capital}

\subsubsection{Teaching practices, Trust and Civic life}

This section looks at the broader implications of teaching practices for trust and civic life at the country level. Figures 5 shows the relationship between the country level of trust and the gap between "Vertical Teaching" and "Horizontal Teaching." Trust is measured by the standard question from the World Values Survey 2000: "In general do you think you can trust others or one cannot be too careful?" The answer is 1 if the respondent trusts others, and zero otherwise. We calculate the country average level of trust. Vertical and Horizontal teaching measures are taken from TIMSS. Vertical teaching is measured by the variable "Students take notes from the board", which ranges from 1 for never to 4 for always. Horizontal teaching is measured by the variable "Students work in groups", with the same scaling. We take the difference between the two. The correlation between this difference and trust is strongly negative; almost one third of the cross-country variation in trust is explained by the variation in teaching practices. Scandinavian countries (with the exception of Finland), and to a lesser extent Anglo-Saxon countries, combine both a fairly high level of trust and teaching practices tilted toward horizontal rather than vertical. In contrast, most Mediterranean (Turkey, France and Greece in the first place) and East European countries are characterized by teaching practices biased toward the vertical and low levels of trust. The big outliers are Japan and Ireland, which tilt toward vertical teaching practices but have high trust.

Table 8 documents the robustness of the relationships between generalized trust and teaching practices by including income per capita, school expenditure per student, and average years of education at the country level. Table 8 - Col.1-2 show a negative correlation between generalized trust and the share of students who always take notes from the board. The coefficient is statistically significant at the 1 percent level. Column 3 shows that this negative relationship is also statistically significant at the 1 percent level with the gap in the time spent by students in taking notes from the board and working in groups. Teaching practices are statistically more significant than national education, a variable usually seen to be the main determinant of trust. The relationship is also economically sizeable. Respectively 33 percent and 32 percent of the cross-country variation in generalized trust is explained by the variation in the variables "Always take notes from the board" and "Gap between Lecture and Work in groups". An increase by one standard deviation in "Always takes notes from the board" is associated with a rise by 5.7 percentage points in generalized trust. 


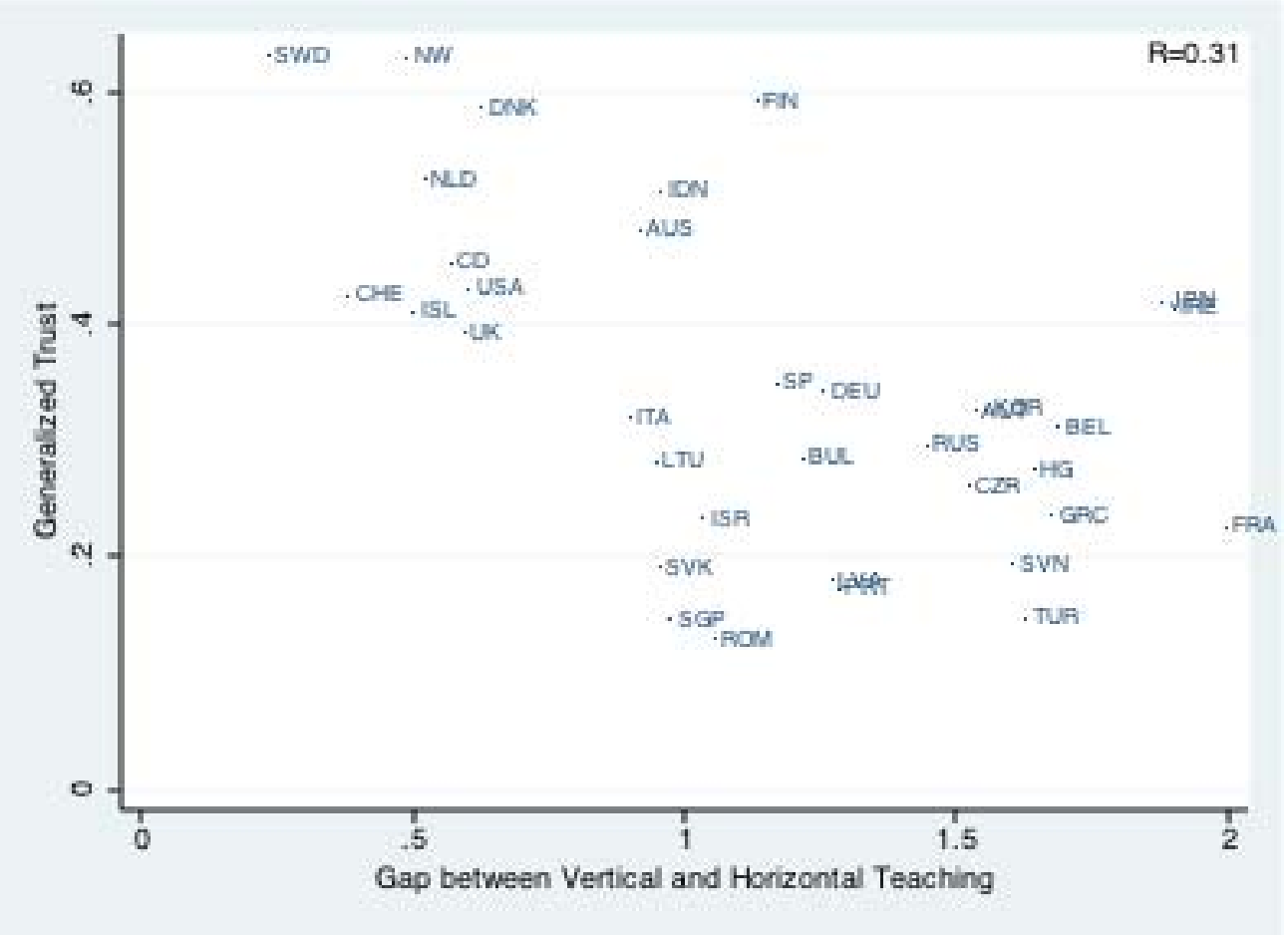

Table 8 - Col. 4-6 show that teaching practices are also significantly related to civic life, measured as the percentage of citizens registered in an association in the WVS 2000. In particular, there is a negative and statistically significant (at the 1 percent level) relationship between vertical teaching and association membership. Taken alone, vertical teaching explains 48 percent of the cross-country variation in association membership, while the level of education taken alone explains 44 percent of the cross-country variation.

Table 9 documents the effects of teaching practices on attitudes toward officials. One might expect vertical teaching to fuel a sense of subordination of citizens to officials, breeding distrust in politics and the state. In contrast, horizontal teaching might encourage a feeling of belonging to the same community and an expectation of accountability from the official. We investigate this hypothesis by using the International Social Survey Program 2006 devoted to the role of government. The ISSP 2006 covers 24 countries for which we have data on teaching practices. We use the following related questions: "Most civil servants can be trusted to do what is best for the country". The answers range from 1 for Strongly Agree, 2 for Agree, 3 for Neither Agree nor Disagree, 4 for Disagree and 5 for Strongly Disagree. The second question is related to the perception of fairness of 
civil servants: "In your opinion, how often do public officials deal fairly with people like you?". The answers range from 1 for Almost always, 2 for Often, 3 for Occasionally, 4 for Seldom and 5 for Almost never. We calculate the country average of the answers to these two questions.

Table 9 shows that the variables trust in civil servants and trust in their fairness are negatively correlated with vertical teaching; both relationships are statistically significant at the 1 percent level. In contrast, horizontal teaching does not display any significant relationship with attitudes toward civil servants. To interpret the magnitude of the effect, we recode the attitudes towards the civil servants. Take the question "In your opinion, how often do public officials deal fairly with people like you?". We create an indicator of the fairness of civil servants equal 1 if the answers are "Almost always" and "Often", and 0 otherwise. We then use the country average share of this variable as the left hand side variable. All the controls are the same as the ones used in Table 9. In this case, an increase by ten percentage points in the share of students who always take notes from the board is associated with a fall 6.7 percentage points in the share of citizens who believe that civil servants treat them fairly.

\subsubsection{Organization of firms}

This section evaluates the consequences of teaching practices for the organization of firms and the quality of labor relations. We assess whether a society emphasizing horizontal teaching also promotes horizontal organization of work in firms. The idea is that citizens who have been trained to cooperate at schools are also more likely to cooperate at work. Conversely, vertical teaching might encourage hierarchical relationships outside of school, and in particular at work. We test this prediction by looking at various cross-country indicators on firm organization.

Figure 6 shows the cross-country relationship between the gap in Vertical and Horizontal teaching and decentralization of firms. Decentralization is measured using the following question from the Global Competitiveness Report 2009 (GCR): "In your country, how do you assess the willingness to delegate authority to subordinates? 1 = low: top management controls all important decisions; 7 = high: authority is mostly delegated to business unit heads and other lower-level managers". The GCR is based on a survey given to a representative sample of managers in all the countries for which we have indicators of teaching practices. This indicator of delegation has been found by Bloom and Van Reenen (2010) to be highly correlated with their own cross-country measure of decentralization in firms. Figure 6 shows a strong negative relation between this indicator of decentralization and the gap between Vertical and Horizontal teaching. Both AngloSaxon and Scandinavian firms are much more decentralized than the European, and especially the Mediterranean and the East European ones, paralleling the patterns in teaching practices. 
Figure 6-Decentralization of firms

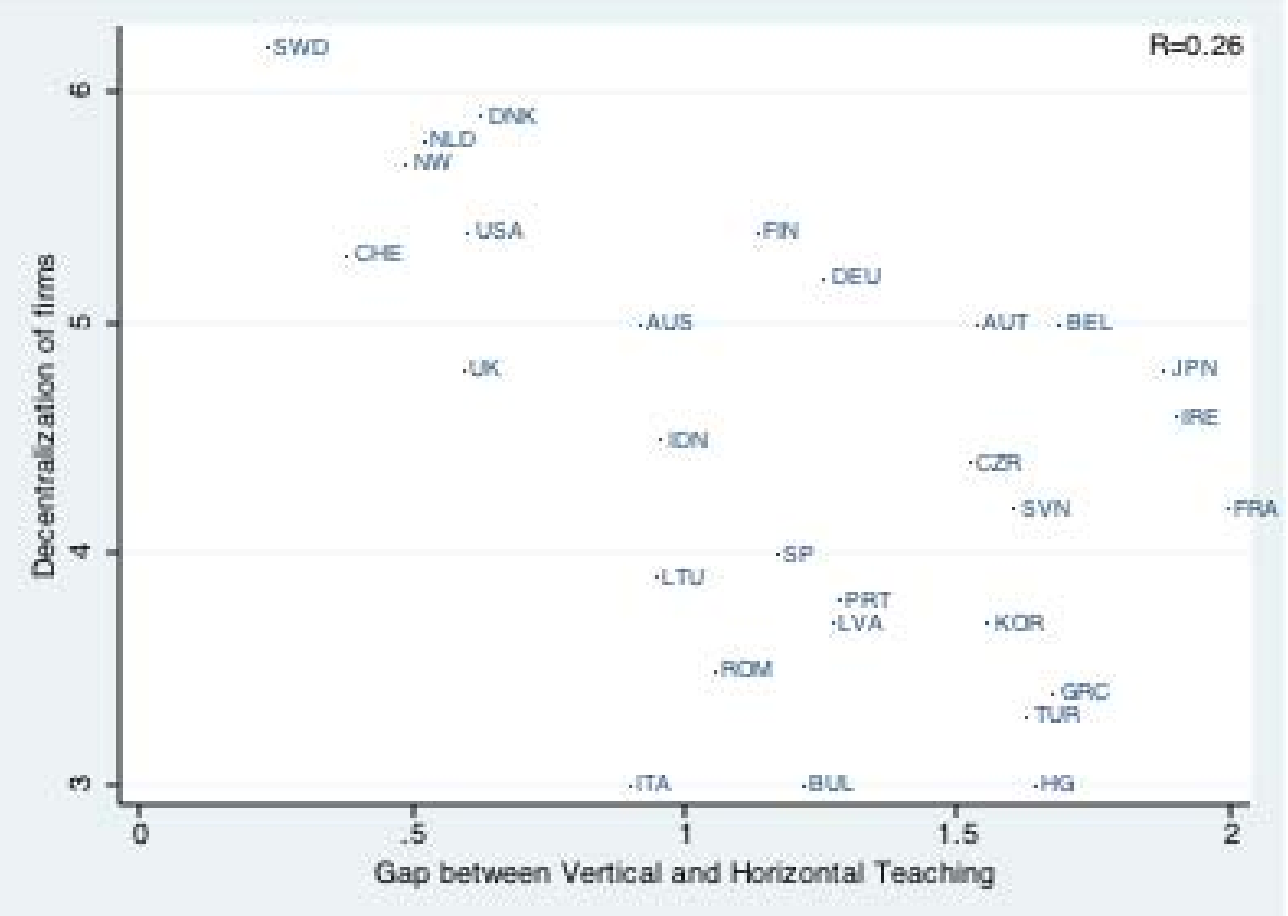

Table 10 - Col. 1-3 confirms that the organization of firms is associated with teaching practices, even with additional controls. Delegation of authority is lower when horizontal teaching is rare, and is negatively correlated with vertical teaching or the gap between vertical and horizontal teaching. The coefficients are statistically significant at the 1 or 5 percent. Taken alone, vertical teaching explains a quarter of the cross-country dispersion in the delegation of authority.

Table 10 - Col. 4-6 provides the complementary picture from the point of view of the workers on their degree of autonomy in the organization of their daily work. The question is taken from the European Social Survey and reads: "When you think about your work, how much freedom do you have in the organizations of your tasks". The answer ranges from 1 for no freedom at all to 10 for total freedom. The results show that workplace autonomy is negatively and significantly correlated with vertical teaching and the gap between vertical and horizontal teaching.

We also investigate how these differences in teaching practices relate to the quality of labor relations. From the GCR 2009, we use the question: "How would you characterize labor-employer relations in your country? 1 = generally confrontational; 7 = generally cooperative." Since the data come from the GCR, this question captures the point of view of managers and executives. 
Figure 7-Quality of labor relations

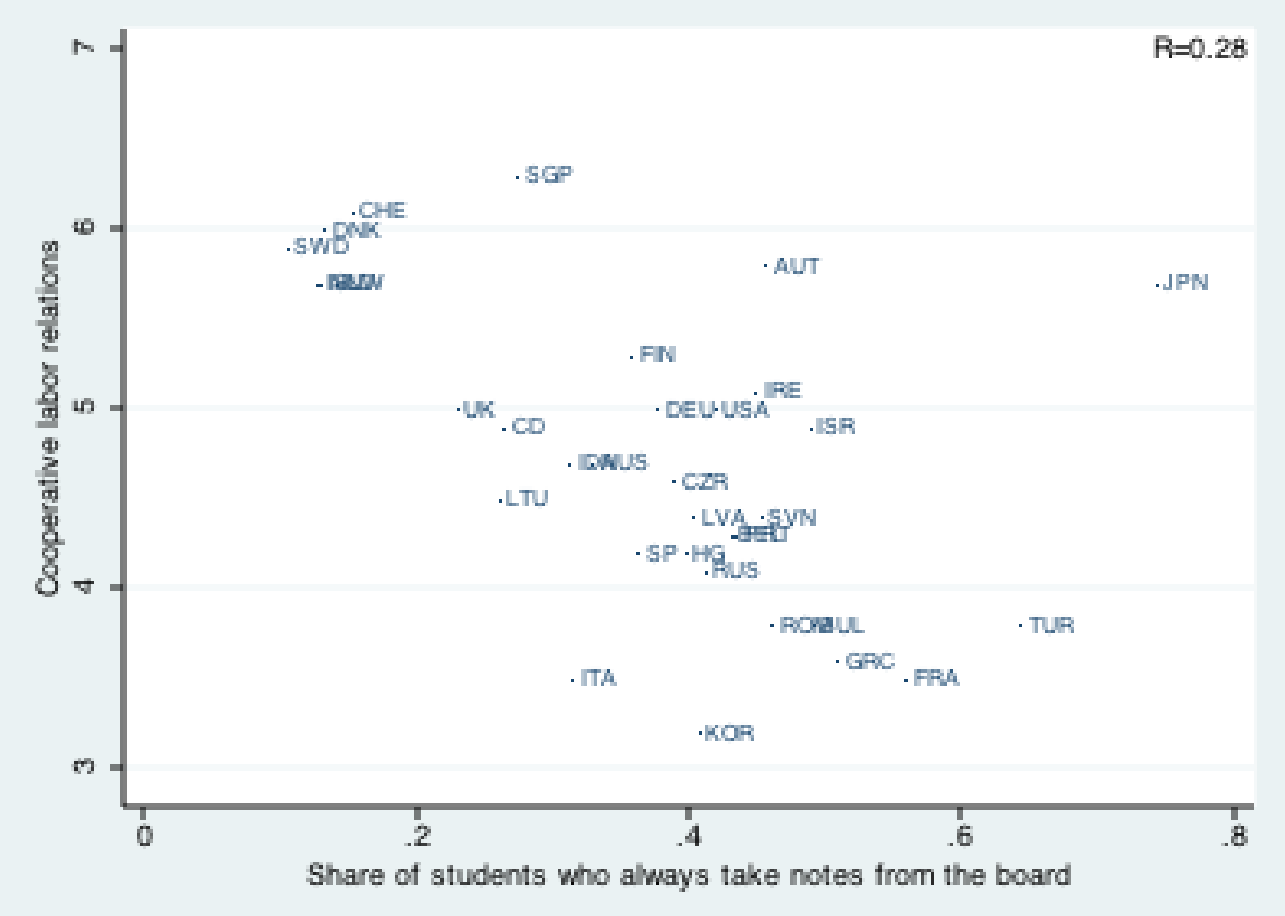

Figure 7 shows that countries in which students always take notes from the board do not have cooperative labor relations. Twenty eight percent of the cross-country variation in the quality of labor relations is explained by vertical teaching. Table 10 tests the robustness of this relationship when we include additional controls. Columns 7-10 show that the quality of labor relations is reduced when horizontal teaching is low and vertical teaching is high. The correlation is the most significant with the gap between the time spent in vertical and horizontal teaching.

\subsubsection{The Quality of Institutions}

We conclude this section by looking at the more general implications of the organization of schools for institutional quality. We first explore the relationship between teaching practices and the extent of regulation of the society. One might expect vertical teaching to be associated with a more hierarchical organization of the state. We look at this using two main indicators. The first is the degree of accountability and effectiveness of government. We take the average of the Kaufmann government effectiveness index between 1998 and 2007 (see Kaufmann et al., 2008). The measure captures perceptions of the quality of public services, the quality of civil service, and its degree of independence from political pressures, the quality of policy formulation and implementation, and 
the credibility of the government's commitment to such policies. The range of the score is from -2.5 to +2.5 , with a higher score indicating better government effectiveness. The second institutional measure is regulatory activity by the state, which we measure with the number of steps for starting a new business from Djankov et al. (2002).

Table 11 - Col. 1-3 show that government effectiveness is lower in countries where the time spent in horizontal teaching is scarce and the time spent in vertical teaching is high. The correlation patterns are statistically significant and economically sizeable. Vertical teaching alone can explain 18.3 percent of the cross-country variation in government effectiveness. Table 10 - Col. 4-6 reports the relationship between entry regulation and teaching practices. Regulation is the more stringent in countries where students spend most of their time in vertical teaching, the coefficient is statistically significant at the 5 percent level.

Table 12 shows that vertical teaching is also associated with a more widespread feeling of corruption from the elites. From the ISSP 1996, we use the following question on the perception of corruption of civil servants: "In your opinion, how many public officials are involved in corruption?". The answers range from 1 for Almost None, 2 for $A$ few, 3 for Quite a lot, and 4 for Almost all. Table 12 - Col. 1-3 shows that this index of perception of corruption is higher the lower the time spent by students in horizontal teaching and the higher the time spent in vertical teaching. The coefficients are statistically significant at the 1 percent level. Table 12 - Col. 4-6 look at the effect of teaching practices for one additional index of corruption. We us the country average score of the Kaufmann index of transparency of institutions over the period 2003-2005. The range of the score is from -2.5 to +2.5 , with a higher score indicating more transparent institutions. The results are very similar.

\subsection{Social capital and patterns of cooperation}

The previous section has shown that teaching practices are highly correlated with student beliefs about cooperation with each other and with teachers. One might wonder which of these is more important in supporting trust and social capital. Following Putnam (2000), most of the literature considers cooperation between equals as the foundation of generalized trust. This paper provides an opportunity to compare the roles of cooperation between equals, and cooperation in a hierarchical relationship, as perceived by the students. We use the indicators of cooperation constructed in section 4.1 .

Table 13 looks at the relationship between the country level of trust and cooperation at schools. We find that generalized trust is positively related to the perception of cooperation with teachers. The correlation is statistically significant at the 5 percent level and is economically sizeable. 
Interestingly, the relationship is weaker between belief in cooperation with peers and generalized trust. However, the picture is the reverse for association membership. Cooperation with teachers does not display any statistically significant relationship with the share of citizens who belong to an association. In contrast, there is a positive and statistically significant relationship between belief in cooperation among peers and association membership.

These results suggests that both aspects of social capital are relevant, but for different results. Generalized trust is more related to the perception that authorities are cooperative or fair. Trust is lower when these relationships are seen as unfair. Civic life is more related to the ability to cooperate and work with peers. To put it differently, learning to cooperate in groups at schools seems to train people how to cooperate more generally in their life. But this does not mean necessarily that these people trust others. In contrast, the degree of fairness felt in vertical relationships is directly related to generalized trust.

We explore further the roles of cooperation with peers and teachers at schools relative to other indicators of cooperation that have been found to be correlated with social capital in the previous literature. La Porta et al. (1997) show that the prevalence of hierarchical religion in a country is negatively correlated with trust and association membership. Aghion et al. (2010) show that civil law versus common law, seen as proxies for different styles of social control of business, are also related to social capital. Table 13 - Column 3 shows that the perception of cooperation with teachers is the only variable related to trust even when we include these additional controls. Column 6 shows that the perception of cooperation with peers remains statistically significant at the 5 percent level with association membership. These results suggest that teaching practices at schools are not merely proxies for other institutional factors. The style of education matters in its own right for the building of social capital, and might be more important than the other factors identified so far in the literature.

\section{Teaching practices and Cognitive skills}

Are teaching practices also related to student cognitive performance? This section addresses this question both at the individual and country level.

We use the TIMSS database for the micro estimates. TIMSS report test scores in mathematics for students in $8^{\text {th }}$ Grade, along with teaching practices and student backgrounds. TIMSS math performance is measured on an international achievement scale with the international mean of 500 
and the international standard deviation of 100 . These achievement tests are evidently representative of national cognitive skills and have been endorsed by all the participating countries (see Martin and Kelly 1997).

We measure teaching practices using the variables: "Students take notes from the board" and "Students work in groups". Recall that these variables range from 1 for Never, 2 for Sometimes, 3 for Often, to 4 for All the time. We also consider dummies for measuring the frequency of each teaching practice to detect potential non-monotonic effects.

The regressions control for several student, teacher, and school characteristics. From the student survey, we use information on family background, including parental education (1=Finish primary school, 2=Finish some secondary school, 3= Finish secondary school, 4= Some vocational education, 5= Some university, $6=$ =Finish university), and the number of books at home ( 1 for None, 2 for One-Ten books, 3 for Eleven-Fifty Books, 4 for Fifty one- One hundred books, 5 for One-hundred and one-Two hundreds books, and 6 for More than two hundred books). We also include student age, as well as dummies for whether the student was born abroad and whether she is a girl. From the teacher survey, we include the teacher's age, gender, highest level of formal education, and years of experience. We also use the size of the classroom in which that teacher teaches that student. From the school principal's survey, we use variables indicating the shortage of instruction materials in the school (equal to 1 for None, 2 for A little, 3 for Some, and 4 for A lot) and the community location of the school (1 for Geographically isolated area, 2 for Village or rural area, 3 for On the outskirts of a city, and 4 for Center of the city).

Table 14 presents the micro estimates. All the regressions control for country fixed effects. Column 1 shows that "Take notes from the board" is statistically significantly negatively related to math performance. The more frequently students take notes from the board, the lower are their test-scores. However, Column 2 shows the same negative relationship between math test scores and "Students work in groups", indicating that math performance declines with the time spent working in groups. The relationships for the two teaching practices are both statistically significant at the 1 percent level. However, the coefficient on "Students work in groups" is lower than that on "Take notes from the board." This evidence suggests that it might be useful to look for nonmonotonic effects of teaching practices.

We do so by including in the regressions dummies for each frequency of each teaching practice. We take the frequency "Never" as the reference group. Column 3 shows that taking notes from the board "Sometimes" instead of "Never" is positively associated with math performance. However, the relationship between math test scores and taking notes from the board "Often" and 
"Always" is negative. Column 4 shows that a similar non-monotonic pattern emerges between math performance and the frequency with which "Students work in groups".

The size of the coefficients associated with teaching practices is quite substantial. Consider the coefficients on the dummies for the frequency of each teaching practice (Col. 3 and 4). Students who work in groups "Sometimes" perform 7.88 test-score points better than students who "Never" work in groups. This effect is of the same order of magnitude as having a teaching with one higher educational degree, the only other teacher characteristic to be statistically significant at the 1 percent level. This effect is comparable to an increase of one and a half steps in the education of the mother or the father. Working in groups "Often", instead of "Never", has a negative but not statistically significant effect on test performance. But students who "Always" work in groups perform 23.82 test score points lower than students who "Never" work in groups. This effect is twice as large as that of being an immigrant. The magnitude of the coefficients on "Taking notes from the board" is smaller. Students who take notes from the board "Sometimes" instead of "Never" do not significantly improve their test scores. Yet students who take notes "Often" or "Always" perform 10.97 and 15.84 points lower than students who "Never" take notes from the board.

We conclude by looking at the aggregate implications of teaching practices for cognitive skills. For the macro estimates, we compute country average tests scores from TIMSS. We also use the information on cognitive tests of 15 year old students provided by PISA 2000, 2003, 2006. From PISA, we also take the country's share of repeaters in secondary schools and the country average value of the PISA index on socio-economic inequality in cognitive scores. This index measures the effect of the socioeconomic background of each student on his cognitive tests. The background includes income and the level of education of the family. The higher is the coefficient, the higher is the role played by the socioeconomic origin of the student in his test scores. We average the coefficients at the country level.

Table 15 presents the OLS estimates of cognitive skills controlling for income per capita and school expenditure. We report the results for the tests score in mathematics from TIMSS 1995. We do not find any statistically significant relationship between test scores and teaching practices. We have checked with PISA cognitive tests, without finding any effects either. Yet Table 15 indicates that the average years of education are negatively related to vertical teaching. This seems to suggest that even though teaching practices are not directly associated with the cognitive skills at a given grade, they might influence the selection of students into upper grades.

Table 16 documents the implications of teaching practices for the share of repeaters and the 
index of socioeconomic inequality. It is consistent with the previous results. More vertical teaching is associated with a higher share of repeaters in secondary schools and a higher weight of socioeconomic backgrounds.

\section{Conclusion.}

We have documented a significant relationship between teaching practices and social capital-supporting beliefs for a sample of about 30,000 students from about 30 countries. Horizontal teaching practices, such as working in groups, seem to promote the formation of social capital, while vertical teaching practices, such as copying from the board, seem to discourage it. We have developed several approaches to suggest that these correlations reflect causal effects, and not omitted variable bias. Overall, it appears that schools, and not just families, work to perpetuate social capital.

We have also shown that, in a cross-section of countries, teaching practices are associated both with beliefs supporting social capital, and several outcomes bearing on the organization of firms and governments. Although extreme horizontal teaching practices seem associated with inferior test performance, so do extreme vertical teaching practices. From the point of academic achievement, the optimum seems to be in the middle.

Throughout the paper, we have focused on the social capital payoff of horizontal teaching practices. Yet there is a substantial and growing body of thought that non-cognitive skills, which seem intimately related to social capital, have an economic payoff as well (see, for example, Heckman 2008, Brunello and Schlotter 2010). The relationship between teaching practices and economic performance of students is one of many open areas that need to be explored. 


\section{References}

Aghion, P., Y. Algan, P. Cahuc, and A. Shleifer, (2010). "Regulation and Distrust," Quarterly Journal of Economics, 125(3): 1015-1049.

Algan, Y., and P. Cahuc, (2010). "Inherited Trust and Growth," American Economic Review, forthcoming.

Almond, G., and S. Verba, (1989, 1st ed. 1963). The Civic Culture: Political Attitudes and Democracy in Five Nations. London: Sage Publications.

Banfield, Edward C., (1958). The Moral Basis of a Backward Society. New York: Free Press.

Barro, R., and J. W. Lee, (2001). "International Data on Educational Attainment: Updates and Implications," Oxford Economic Papers, 53: 541-563.

Benabou, and J. Tirole, (2010). "Identity, Morals, and Taboos: Beliefs as Assets," Quarterly Journal of Economics, forthcoming.

Bisin, A., and T. Verdier, (2001). "The Economics of Cultural Transmission and the Dynamics of Preferences," Journal of Economic Theory, 97(2): 298-319.

Bloom, N., and J. Van Reenen, (2010). "Why Do Management Practices Differ across Firms and Countries?" Journal of Economic Perspectives, 24(1): 203-224.

Bloom, N., R. Sadun, and J. Van Reenen, (2007). "The Organization of Firms Across Countries," Stanford University Mimeo.

Bourdieu, and Passeron, (1970).

Bowles, S., and H. Gintis, (1976). Schooling in Capitalist America: Educational Reform and the Contradictions of Capitalist Life. New York: Basic Books.

Brunello, G., and M. Schlotter, (2010). "The Effect of Non Cognitive Skills and Personality Traits on Labour Market Outcomes," working paper.

Coleman, J., (1990). Foundations of Social Theory. Cambridge, MA: Harvard University Press.

Croson, R., and U. Gneezy, (2009). "Gender Differences in Preferences," Journal of Economic Literature, 47(2): 1-27.

Djankov, S., R. La Porta, F. Lopez-de-Silanes, and A. Shleifer, (2002). "The Regulation of Entry," Quarterly Journal of Economics, 117(1):1-37.

Djankov, S., E. Glaeser, R. La Porta, F. Lopez-de-Silanes, and A. Shleifer, (2003). "The New Comparative Economics," Journal of Comparative Economics, 31: 595-619.

Guiso, L., P. Sapienza, and L. Zingales, (2004). "The Role of Social Capital in Financial Development," American Economic Review, 94(3): 526-56.

Guiso, L., P. Sapienza, and L. Zingales, (2007). "Long Term Persistence," University of Chicago, 
Mimeo.

Guiso, L., P. Sapienza, and L. Zingales, (2008). "Social Capital as Good Culture," Journal of the European Economic Association Papers and Proceedings, 6: 295-320.

Guiso, L., P. Sapienza, and L. Zingales, (2009). “Cultural Biases in Economic Exchange?” Quarterly Journal of Economics, 124(3): 1095-1131.

Guiso, L., P. Sapienza, and L. Zingales, (2010). “Civic Capital as the Missing Link,” NBER Working Paper No. 15845.

Glaeser, E., G. Ponzetto, and A. Shleifer, (2007). “Why Does Democracy Need Education?” Journal of Economic Growth, 12:77-99.

Hanushek, E., and L. Woessmann, (2010). "The Economics of International Differences in Educational Achievement," IZA working paper.

Heckman, J., (2008). "Schools, Skills and Synapses," Economic Inquiry, 46(3): 289-324.

Helliwell, J., and R. Putnam, (2007). “Education and Social Capital,” Eastern Economics Journal, 33(1): 1-19.

Kaufmann, D., A. Kraay, and M. Mastruzzi, (2008). “Governance Matters VII: Aggregate and Individual Governance Indicators 1996-2007," World Bank Policy Research Working Paper 4654.

Knack, S., and P. Keefer, (1997). "Does Social Capital Have an Economic Payoff? A Cross-Country Comparison," Quarterly Journal of Economics, 112: 1251-1288.

La Porta, R., F. Lopez-de-Silanes, A. Shleifer, and R. Vishny, (1997). "Trust in Large Organizations," American Economic Review Papers and Proceedings, 87(2): 333-338.

La Porta, R., F. Lopez-de-Silanes, and A. Shleifer, (2008). "The Economic Consequences of Legal Origins," Journal of Economic Literature, 46: 285-332.

Lipset, S. M., (1959). "Some Social Requisites for Democracy: Economic Development and Political Legitimacy," American Political Science Review, 53: 69-105.

Martin and Kelly, (1997).

Putnam, R., (1993). Making Democracy Work. Princeton, NJ: Princeton University Press.

Putnam, R., (2000). Bowling Alone: The Collapse and Revival of American Community. New York: Simon \& Schuster.

Schuetz et. al., (2008).

Tabellini, G., (2008). "The Scope of Cooperation: Norms and Incentives," Quarterly Journal of Economics, 123: 905-950.

Woessmann, L., (2003). "Schooling Resources, Educational Institutions, and Student Performance: The International Evidence," Oxford Bulletin of Economics and Statistics, 65: 117-170.

Woessmann, L., (2005). "Educational Production in Europe," Economic Policy, 43: 446-504. 


\section{TABLES}

Table 1a-Correlations between Teaching practices. Source: CES

\begin{tabular}{l|lllllll}
\hline $\begin{array}{l}\text { Variables } \\
\text { CES }\end{array}$ & Lecture & Group & Textbook & Questions & Discussion & Project Events \\
\hline Lecture & & & & & & \\
Group & -.376 & & & & & & \\
Textbook & .671 & -.414 & & & & & \\
Questions & .715 & -.743 & .546 & & & & \\
Discussion & .394 & -.068 & .233 & .349 & & & \\
Projects & -.148 & .746 & -.235 & -.486 & -.197 & & \\
Events & .344 & -.227 & .109 & .372 & .213 & -.344 & \\
Play & -.150 & .340 & -.140 & -.193 & -.067 & .229 & .22 \\
\hline
\end{tabular}

Table $1 b$ - Factor Analysis of teaching practices. Source: CES

\begin{tabular}{l|ll}
\hline Factor Analysis & $\begin{array}{l}\text { Vertical } \\
\text { teaching } \\
\text { Factor 1 }\end{array}$ & $\begin{array}{l}\text { Horizontal } \\
\text { Teaching }\end{array}$ \\
& Factor 2 \\
\hline Lecture & .835 & -.092 \\
Group & -.416 & .824 \\
Textbook & .748 & -.414 \\
Questions & .758 & -.743 \\
Discussion & .179 & .198 \\
Projects & -.108 & .819 \\
Events & .366 & -.214 \\
Play & -.232 & .188 \\
\hline
\end{tabular}


Table $1 \mathrm{c}$ - Correlations between Teaching practices across CES and TIMSS surveys

\begin{tabular}{|c|c|c|c|c|}
\hline Variables & $\begin{array}{l}\text { Teachers } \\
\text { Lecture } \\
\text { CES }\end{array}$ & $\begin{array}{l}\text { Students work in } \\
\text { groups } \\
\text { CES }\end{array}$ & $\begin{array}{l}\text { Principal } \\
\text { Component - } \\
\text { Vertical teaching } \\
\text { CES }\end{array}$ & $\begin{array}{l}\text { Principal } \\
\text { component } \\
\text { Horizontal } \\
\text { teaching CES }\end{array}$ \\
\hline $\begin{array}{l}\text { Students take } \\
\text { notes from } \\
\text { the board - } \\
\text { TIMSS }\end{array}$ & .324 & -.404 & .445 & -.352 \\
\hline $\begin{array}{l}\text { Students } \\
\text { work in } \\
\text { groups- } \\
\text { TIMSS }\end{array}$ & .190 & .598 & .018 & .639 \\
\hline
\end{tabular}


Table 2 - Student belief in cooperation among students: OLS Microestimates. Source: CES

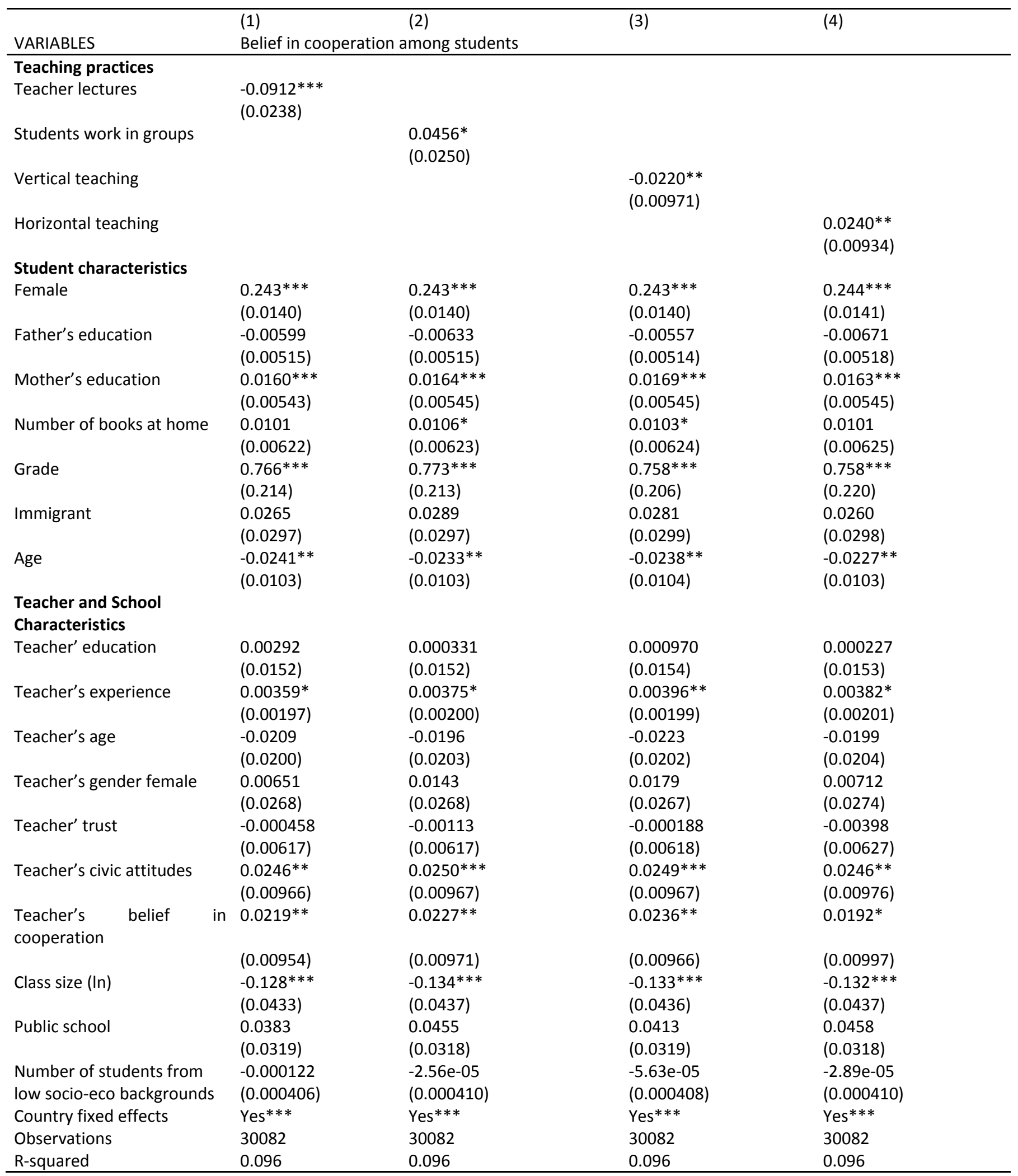


Table 3 - Student belief in cooperation between students and teachers: OLS Microestimates. Source: CES

\begin{tabular}{|c|c|c|c|c|}
\hline \multirow{2}{*}{ VARIABLES } & (1) & $(2)$ & (3) & (4) \\
\hline & \multicolumn{4}{|c|}{ Belief in cooperation between students and teachers } \\
\hline \multicolumn{5}{|l|}{ Teaching practices } \\
\hline Teacher lectures & $\begin{array}{l}-0.0905^{* *} \\
(0.0369)\end{array}$ & & & \\
\hline \multicolumn{2}{|l|}{ Students work in groups } & $\begin{array}{l}0.0955^{* *} \\
(0.0390)\end{array}$ & & \\
\hline \multicolumn{2}{|l|}{ Vertical teaching } & & $\begin{array}{l}-0.0518 * * * \\
(0.0151)\end{array}$ & \\
\hline \multicolumn{2}{|l|}{ Horizontal teaching } & & & $\begin{array}{l}0.0575 * * * \\
(0.0134)\end{array}$ \\
\hline \multicolumn{5}{|l|}{ Student characteristics } \\
\hline Female & $\begin{array}{l}0.423^{* * *} \\
(0.0191)\end{array}$ & $\begin{array}{l}0.422 * * * \\
(0.0191)\end{array}$ & $\begin{array}{l}0.422 * * * \\
(0.0191)\end{array}$ & $\begin{array}{l}0.423 * * * \\
(0.0191)\end{array}$ \\
\hline Father's education & $\begin{array}{l}0.0246 * * * \\
(0.00706)\end{array}$ & $\begin{array}{l}0.0241 * * * \\
(0.00706)\end{array}$ & $\begin{array}{l}0.0254 * * * \\
(0.00705)\end{array}$ & $\begin{array}{l}0.0236 * * * \\
(0.00708)\end{array}$ \\
\hline Mother's education & $\begin{array}{l}0.00424 \\
(0.00737)\end{array}$ & $\begin{array}{l}0.00514 \\
(0.00738)\end{array}$ & $\begin{array}{l}0.00566 \\
(0.00738)\end{array}$ & $\begin{array}{l}0.00555 \\
(0.00741)\end{array}$ \\
\hline Number of books at & $\begin{array}{l}0.0441 * * * \\
(0.00846)\end{array}$ & $\begin{array}{l}0.0447^{* * *} \\
(0.00849)\end{array}$ & $\begin{array}{l}0.0448 * * * \\
(0.00847)\end{array}$ & $\begin{array}{l}0.0443 * * * \\
(0.00852)\end{array}$ \\
\hline Grade & $\begin{array}{l}0.0989 \\
(0.429)\end{array}$ & $\begin{array}{l}0.120 \\
(0.438)\end{array}$ & $\begin{array}{l}0.0899 \\
(0.455)\end{array}$ & $\begin{array}{l}0.0860 \\
(0.420)\end{array}$ \\
\hline Immigrant & $\begin{array}{l}0.0267 \\
(0.0406)\end{array}$ & $\begin{array}{l}0.0305 \\
(0.0408)\end{array}$ & $\begin{array}{l}0.0363 \\
(0.0402)\end{array}$ & $\begin{array}{l}0.0286 \\
(0.0410)\end{array}$ \\
\hline Age & $\begin{array}{l}-0.0149 \\
(0.0140)\end{array}$ & $\begin{array}{l}-0.0140 \\
(0.0140)\end{array}$ & $\begin{array}{l}-0.0166 \\
(0.0140)\end{array}$ & $\begin{array}{l}-0.0114 \\
(0.0139)\end{array}$ \\
\hline \multicolumn{5}{|l|}{$\begin{array}{l}\text { Teacher and School } \\
\text { characteristics }\end{array}$} \\
\hline Teacher's Education & $\begin{array}{l}0.00789 \\
(0.0249)\end{array}$ & $\begin{array}{l}0.00492 \\
(0.0250)\end{array}$ & $\begin{array}{l}0.00599 \\
(0.0253)\end{array}$ & $\begin{array}{l}0.00575 \\
(0.0251)\end{array}$ \\
\hline Teacher's Experience & $\begin{array}{l}-0.000360 \\
(0.00371)\end{array}$ & $\begin{array}{l}-0.000307 \\
(0.00375)\end{array}$ & $\begin{array}{l}1.23 e-05 \\
(0.00374)\end{array}$ & $\begin{array}{l}-0.000134 \\
(0.00376)\end{array}$ \\
\hline Teacher's Age & $\begin{array}{l}-0.0128 \\
(0.0363)\end{array}$ & $\begin{array}{l}-0.0102 \\
(0.0368)\end{array}$ & $\begin{array}{l}-0.0143 \\
(0.0365)\end{array}$ & $\begin{array}{l}-0.0111 \\
(0.0371)\end{array}$ \\
\hline Teacher's gender & $\begin{array}{l}-0.0239 \\
(0.0445)\end{array}$ & $\begin{array}{l}-0.0232 \\
(0.0446)\end{array}$ & $\begin{array}{l}-0.0194 \\
(0.0450)\end{array}$ & $\begin{array}{l}-0.0420 \\
(0.0445)\end{array}$ \\
\hline Teacher's Trust & $\begin{array}{l}0.0114 \\
(0.0106)\end{array}$ & $\begin{array}{l}0.00994 \\
(0.0106)\end{array}$ & $\begin{array}{l}0.0118 \\
(0.0107)\end{array}$ & $\begin{array}{l}0.00304 \\
(0.0107)\end{array}$ \\
\hline Teacher's Civic attitudes & $\begin{array}{l}0.0234 \\
(0.0152)\end{array}$ & $\begin{array}{l}0.0236 \\
(0.0153)\end{array}$ & $\begin{array}{l}0.0246 \\
(0.0152)\end{array}$ & $\begin{array}{l}0.0214 \\
(0.0155)\end{array}$ \\
\hline \multirow[t]{2}{*}{$\begin{array}{l}\text { Teacher's belief } \\
\text { cooperation }\end{array}$} & $0.0383^{* *}$ & $0.0371 * *$ & $0.0387^{* *}$ & 0.0258 \\
\hline & $(0.0166)$ & $(0.0167)$ & $(0.0166)$ & $(0.0171)$ \\
\hline Class size (In) & $\begin{array}{l}-0.157^{* *} \\
(0.0685)\end{array}$ & $\begin{array}{l}-0.162 * * \\
(0.0687)\end{array}$ & $\begin{array}{l}-0.152 * * \\
(0.0688)\end{array}$ & $\begin{array}{l}-0.156 * * \\
(0.0685)\end{array}$ \\
\hline Public school & $\begin{array}{l}-0.0689 \\
(0.0529)\end{array}$ & $\begin{array}{l}-0.0601 \\
(0.0528)\end{array}$ & $\begin{array}{l}-0.0684 \\
(0.0531)\end{array}$ & $\begin{array}{l}-0.0578 \\
(0.0526)\end{array}$ \\
\hline $\begin{array}{l}\text { Number of students from } \\
\text { Low socioeco. backgrounds }\end{array}$ & $\begin{array}{l}-0.00127^{*} \\
(0.000667)\end{array}$ & $\begin{array}{l}-0.00117^{*} \\
(0.000674)\end{array}$ & $\begin{array}{l}-0.00123^{*} \\
(0.000673)\end{array}$ & $\begin{array}{l}-0.00111 \\
(0.000674)\end{array}$ \\
\hline Country fixed effects & Yes*** & Yes*** & Yes*** & Yes*** \\
\hline Observations & 27600 & 27600 & 27600 & 27600 \\
\hline R-squared & 0.087 & 0.087 & 0.088 & 0.088 \\
\hline
\end{tabular}


Table 4 - Student involvement in Associations and Teaching practices. OLS Micro-estimates. Source CES

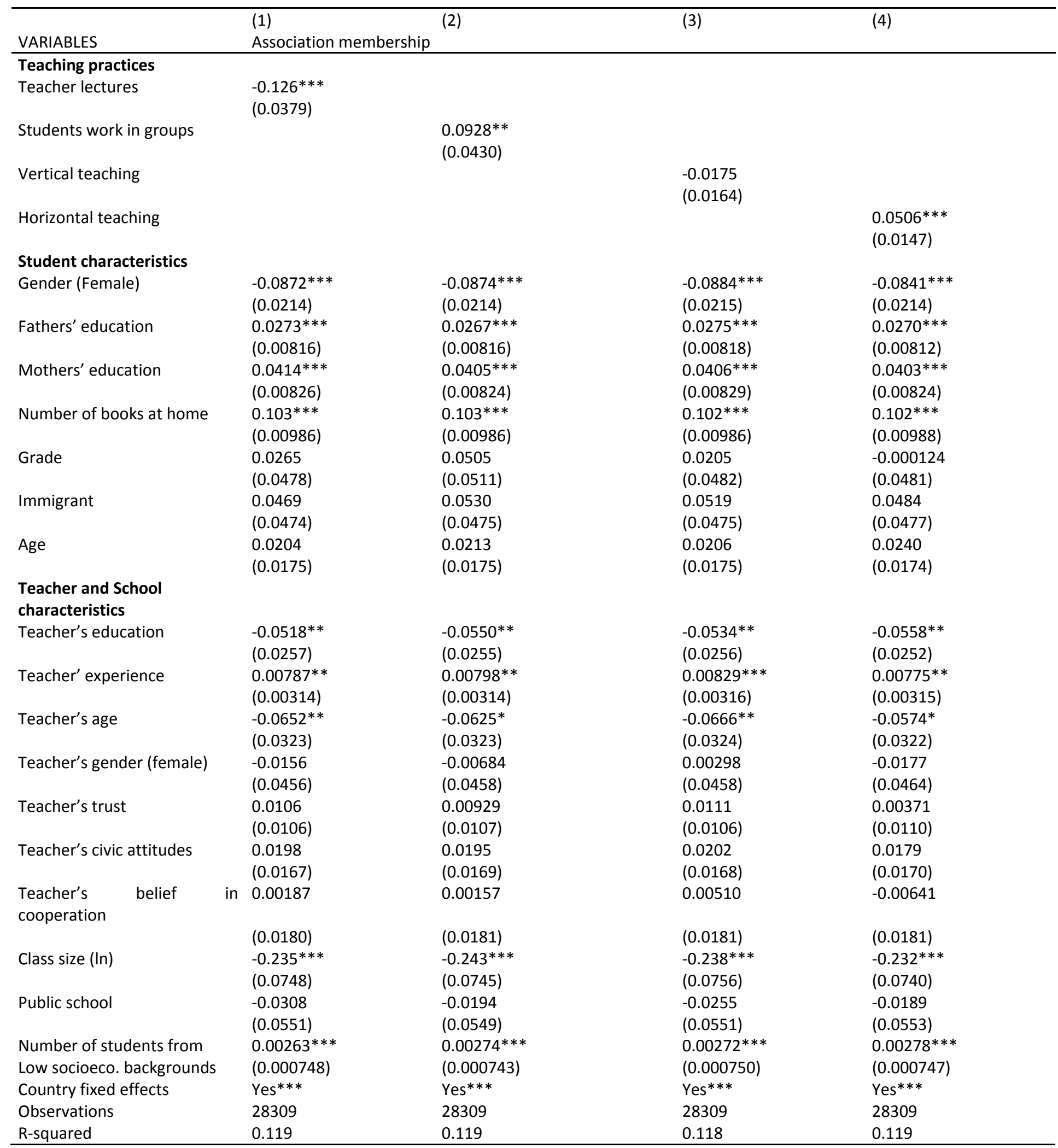


Table 5 - Trust and Teaching practices. OLS micro-estimates. Source CES

\begin{tabular}{|c|c|c|c|c|}
\hline & (1) & $(2)$ & (3) & (4) \\
\hline VARIABLES & Trust & & & \\
\hline \multicolumn{5}{|l|}{ Teaching practices } \\
\hline Teacher lectures & $\begin{array}{l}-0.0164 \\
(0.0214)\end{array}$ & & & \\
\hline Students work in groups & & $\begin{array}{l}0.0120 \\
(0.0233)\end{array}$ & & \\
\hline Vertical teaching & & & $\begin{array}{l}-0.00392 \\
(0.00908)\end{array}$ & \\
\hline Horizontal teaching & & & & $\begin{array}{l}0.0175^{* *} \\
(0.00805)\end{array}$ \\
\hline \multicolumn{5}{|l|}{ Student characteristics } \\
\hline Gender (female) & $\begin{array}{l}0.0982 * * * \\
(0.0138)\end{array}$ & $\begin{array}{l}0.0982 * * * \\
(0.0138)\end{array}$ & $\begin{array}{l}0.0983 * * * \\
(0.0138)\end{array}$ & $\begin{array}{l}0.0993 * * * \\
(0.0139)\end{array}$ \\
\hline Father's education & $\begin{array}{l}0.00575 \\
(0.00507)\end{array}$ & $\begin{array}{l}0.00564 \\
(0.00507)\end{array}$ & $\begin{array}{l}0.00599 \\
(0.00507)\end{array}$ & $\begin{array}{l}0.00533 \\
(0.00509)\end{array}$ \\
\hline Mother's education & $\begin{array}{l}0.0137 * * * \\
(0.00532)\end{array}$ & $\begin{array}{l}0.0139 * * * \\
(0.00532)\end{array}$ & $\begin{array}{l}0.0145 * * * \\
(0.00532)\end{array}$ & $\begin{array}{l}0.0137^{* *} \\
(0.00533)\end{array}$ \\
\hline Number of books at home & $\begin{array}{l}-0.0125 * * \\
(0.00589)\end{array}$ & $\begin{array}{l}-0.0126 * * \\
(0.00590)\end{array}$ & $\begin{array}{l}-0.0118^{* *} \\
(0.00590)\end{array}$ & $\begin{array}{l}-0.0133 * * \\
(0.00591)\end{array}$ \\
\hline Grade & $\begin{array}{l}-1.155^{* * *} \\
(0.309)\end{array}$ & $\begin{array}{l}-1.153^{* * *} \\
(0.309)\end{array}$ & $\begin{array}{l}-1.157^{* * *} \\
(0.308)\end{array}$ & $\begin{array}{l}-1.160 * * * \\
(0.310)\end{array}$ \\
\hline Immigrant & $\begin{array}{l}-0.0421 \\
(0.0281)\end{array}$ & $\begin{array}{l}-0.0417 \\
(0.0281)\end{array}$ & $\begin{array}{l}-0.0386 \\
(0.0282)\end{array}$ & $\begin{array}{l}-0.0418 \\
(0.0281)\end{array}$ \\
\hline Age & $\begin{array}{l}-0.0308 * * * \\
(0.00991)\end{array}$ & $\begin{array}{l}-0.0309 * * * \\
(0.00991)\end{array}$ & $\begin{array}{l}-0.0312 * * * \\
(0.00992)\end{array}$ & $\begin{array}{l}-0.0308 * * * \\
(0.00991)\end{array}$ \\
\hline \multicolumn{5}{|l|}{$\begin{array}{l}\text { Teacher and School } \\
\text { characteristics }\end{array}$} \\
\hline Teacher's education & $\begin{array}{l}-0.0131 \\
(0.0149)\end{array}$ & $\begin{array}{l}-0.0133 \\
(0.0149)\end{array}$ & $\begin{array}{l}-0.0133 \\
(0.0149)\end{array}$ & $\begin{array}{l}-0.0129 \\
(0.0150)\end{array}$ \\
\hline Teacher's experience & $\begin{array}{l}0.00124 \\
(0.00203)\end{array}$ & $\begin{array}{l}0.00123 \\
(0.00203)\end{array}$ & $\begin{array}{l}0.00132 \\
(0.00204)\end{array}$ & $\begin{array}{l}0.00108 \\
(0.00204)\end{array}$ \\
\hline Teacher's age & $\begin{array}{l}0.00646 \\
(0.0201)\end{array}$ & $\begin{array}{l}0.00682 \\
(0.0202)\end{array}$ & $\begin{array}{l}0.00600 \\
(0.0202)\end{array}$ & $\begin{array}{l}0.00835 \\
(0.0203)\end{array}$ \\
\hline Teacher's gender (female) & $\begin{array}{l}-0.0129 \\
(0.0257)\end{array}$ & $\begin{array}{l}-0.0113 \\
(0.0253)\end{array}$ & $\begin{array}{l}-0.00996 \\
(0.0257)\end{array}$ & $\begin{array}{l}-0.0167 \\
(0.0257)\end{array}$ \\
\hline Teacher 's trust & $\begin{array}{l}0.00758 \\
(0.00613)\end{array}$ & $\begin{array}{l}0.00728 \\
(0.00614)\end{array}$ & $\begin{array}{l}0.00762 \\
(0.00614)\end{array}$ & $\begin{array}{l}0.00538 \\
(0.00628)\end{array}$ \\
\hline Teacher's activities & $\begin{array}{l}0.0276 * * * \\
(0.00926)\end{array}$ & $\begin{array}{l}0.0274 * * * \\
(0.00929)\end{array}$ & $\begin{array}{l}0.0275^{* * *} \\
(0.00930)\end{array}$ & $\begin{array}{l}0.0260 * * * \\
(0.00940)\end{array}$ \\
\hline \multirow[t]{2}{*}{$\begin{array}{l}\text { Teacher's belief } \\
\text { cooperation }\end{array}$} & 0.0142 & 0.0142 & 0.0144 & 0.0106 \\
\hline & $(0.00967)$ & $(0.00975)$ & $(0.00965)$ & $(0.0101)$ \\
\hline Class size (In) & $\begin{array}{l}-0.147 * * * \\
(0.0422)\end{array}$ & $\begin{array}{l}-0.148 * * * \\
(0.0422)\end{array}$ & $\begin{array}{l}-0.148 * * * \\
(0.0425)\end{array}$ & $\begin{array}{l}-0.143 * * * \\
(0.0420)\end{array}$ \\
\hline Public school & $\begin{array}{l}0.0201 \\
(0.0333)\end{array}$ & $\begin{array}{l}0.0218 \\
(0.0334)\end{array}$ & $\begin{array}{l}0.0205 \\
(0.0334)\end{array}$ & $\begin{array}{l}0.0225 \\
(0.0335)\end{array}$ \\
\hline $\begin{array}{l}\text { Number of students from } \\
\text { low socioeco. backgrounds }\end{array}$ & $\begin{array}{l}0.000130 \\
(0.000407)\end{array}$ & $\begin{array}{l}0.000140 \\
(0.000407)\end{array}$ & $\begin{array}{l}0.000142 \\
(0.000407)\end{array}$ & $\begin{array}{l}0.000135 \\
(0.000405)\end{array}$ \\
\hline Country fixed effects & Yes*** & Yes*** & Yes*** & Yes $* * *$ \\
\hline Observations & 30500 & 30500 & 30500 & 30500 \\
\hline R-squared & 0.057 & 0.057 & 0.057 & 0.057 \\
\hline
\end{tabular}


Table 6 - "Beliefs in cooperation at schools" - OLS Macro Estimates

\begin{tabular}{|c|c|c|c|c|c|c|}
\hline \multirow[b]{2}{*}{ VARIABLES } & (1) & (2) & (3) & (4) & (5) & (6) \\
\hline & \multicolumn{3}{|c|}{ "Cooperation among students» } & \multicolumn{3}{|c|}{ "Cooperation with teachers» } \\
\hline $\begin{array}{l}\text { Never work } \\
\text { in groups }\end{array}$ & $\begin{array}{l}-5.084^{* *} \\
(.194)\end{array}$ & & & $\begin{array}{l}-3.038^{*} \\
(1.140)\end{array}$ & & \\
\hline $\begin{array}{l}\text { Always take notes } \\
\text { from the board }\end{array}$ & & $\begin{array}{l}-4.712^{* *} \\
(2.274)\end{array}$ & & & $\begin{array}{l}-3.060^{*} \\
(1.031)\end{array}$ & \\
\hline $\begin{array}{l}\text { Gap between } \\
\text { Lecture - Group }\end{array}$ & & & $\begin{array}{l}-1.880^{* * *} \\
(.638)\end{array}$ & & & $\begin{array}{l}-1.345^{* * *} \\
(.395)\end{array}$ \\
\hline $\begin{array}{l}\text { School } \\
\text { expenditure }\end{array}$ & $\begin{array}{l}1.037 \\
(1.431)\end{array}$ & $\begin{array}{l}.472 \\
(1.457)\end{array}$ & $\begin{array}{l}.861 \\
(1.298)\end{array}$ & $\begin{array}{l}.075 \\
(.792)\end{array}$ & $\begin{array}{l}-.244 \\
(.891)\end{array}$ & $\begin{array}{l}-.098 \\
(.835)\end{array}$ \\
\hline Income per capita & $\begin{array}{l}-.498 \\
(.970)\end{array}$ & $\begin{array}{l}-.320 \\
(1.004)\end{array}$ & $\begin{array}{l}-.488 \\
(.891)\end{array}$ & $\begin{array}{l}-.028 \\
(.563)\end{array}$ & $\begin{array}{l}.061 \\
(.619)\end{array}$ & $\begin{array}{l}-.181 \\
(.539)\end{array}$ \\
\hline $\begin{array}{l}\text { Average years of } \\
\text { Education }\end{array}$ & $\begin{array}{l}-.120 \\
(.203)\end{array}$ & $\begin{array}{l}-.161 \\
(.217)\end{array}$ & $\begin{array}{l}-.250 \\
(.195)\end{array}$ & $\begin{array}{l}-.098 \\
(.124)\end{array}$ & $\begin{array}{l}-.129 \\
(.160)\end{array}$ & $\begin{array}{l}-.219 \\
(.153\end{array}$ \\
\hline Observations & 29 & 29 & 29 & 29 & 29 & 29 \\
\hline R-squared & 0.223 & 0.154 & 0.270 & 0.243 & .203 & 0.386 \\
\hline
\end{tabular}


Table 7 -Student feeling of alienation. OLS Macro estimates

\begin{tabular}{|c|c|c|c|c|c|c|}
\hline \multirow[b]{2}{*}{ VARIABLES } & (1) & (2) & (3) & (4) & (5) & (6) \\
\hline & \multicolumn{3}{|c|}{ «Respect Parents» - WVS } & \multicolumn{3}{|c|}{ «Feeling of alienation at school» - PISA } \\
\hline $\begin{array}{l}\text { Never work } \\
\text { in groups }\end{array}$ & $\begin{array}{l}.088 \\
(.120)\end{array}$ & & & $\begin{array}{l}.385 \\
(.999)\end{array}$ & & \\
\hline $\begin{array}{l}\text { Always take notes } \\
\text { from the board }\end{array}$ & & $\begin{array}{l}.385^{* * *} \\
(.115)\end{array}$ & & & $\begin{array}{l}3.816^{*} \\
(.648)\end{array}$ & \\
\hline $\begin{array}{l}\text { Gap between } \\
\text { Lecture - Group }\end{array}$ & & & $\begin{array}{l}.101^{* *} \\
(.036)\end{array}$ & & & $\begin{array}{l}.888^{* *} \\
(.349)\end{array}$ \\
\hline $\begin{array}{l}\text { School } \\
\text { expenditure }\end{array}$ & $\begin{array}{l}.089 \\
(.062)\end{array}$ & $\begin{array}{l}.091 \\
(.057)\end{array}$ & $\begin{array}{l}.080 \\
(.051)\end{array}$ & $\begin{array}{l}1.107^{*} \\
(.639)\end{array}$ & $\begin{array}{l}.889 \\
(.544)\end{array}$ & $\begin{array}{l}.795 \\
(.635)\end{array}$ \\
\hline Income per capita & $\begin{array}{l}-.117^{* *} \\
(.046)\end{array}$ & $\begin{array}{l}-.112^{* *} \\
(.040)\end{array}$ & $\begin{array}{l}-.109 * * * \\
(.035)\end{array}$ & $\begin{array}{l}-.937 \\
(.487)\end{array}$ & $\begin{array}{l}-.708^{*} \\
(.363)\end{array}$ & $\begin{array}{l}-.705 \\
(.469)\end{array}$ \\
\hline $\begin{array}{l}\text { Average years of } \\
\text { Education }\end{array}$ & $\begin{array}{l}-.019 \\
(.009)\end{array}$ & $\begin{array}{l}-.011 \\
(.009)\end{array}$ & $\begin{array}{l}-.010 \\
(.010)\end{array}$ & $\begin{array}{l}.008 \\
(.090)\end{array}$ & $\begin{array}{l}.091 \\
(.069)\end{array}$ & $\begin{array}{l}.090 \\
(.094)\end{array}$ \\
\hline Observations & 31 & 31 & 31 & 29 & 29 & 29 \\
\hline R-squared & 0.471 & 0.639 & 0.583 & 0.161 & 0.557 & 0.369 \\
\hline
\end{tabular}


Table 8 - Teaching practices, Generalized Trust and Association Membership

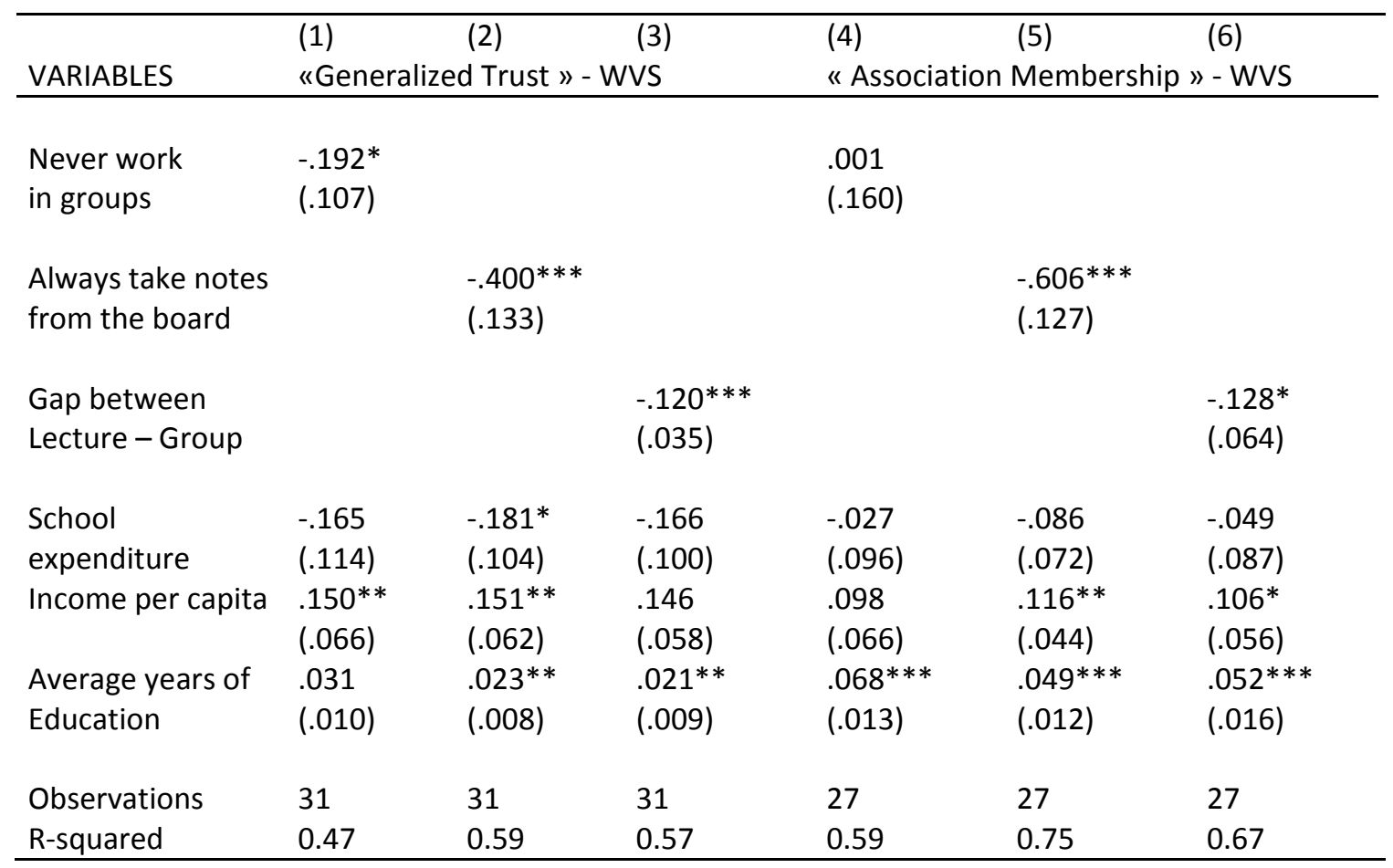


Table 9 - Teaching practices and Trust in public officials

\begin{tabular}{|c|c|c|c|c|c|c|}
\hline \multirow[b]{2}{*}{ VARIABLES } & (1) & $(2)$ & (3) & (4) & (5) & (6) \\
\hline & \multicolumn{3}{|c|}{ Trust in Civil Servants - ISSP } & \multicolumn{3}{|c|}{ Civil Servants treat citizens fairly - ISSP } \\
\hline $\begin{array}{l}\text { Never work } \\
\text { in groups }\end{array}$ & $\begin{array}{l}-.217 \\
(.541)\end{array}$ & & & $\begin{array}{l}-.125 \\
(.433)\end{array}$ & & \\
\hline $\begin{array}{l}\text { Always take notes } \\
\text { from the board }\end{array}$ & & $\begin{array}{l}-1.36 \\
(.567\end{array}$ & & & $\begin{array}{l}-1.906 \\
(.420)\end{array}$ & \\
\hline $\begin{array}{l}\text { Gap between } \\
\text { Lecture - Group }\end{array}$ & & & $\begin{array}{l}-.279 \\
(.253)\end{array}$ & & & $\begin{array}{l}-.392^{*} \\
(.215)\end{array}$ \\
\hline $\begin{array}{l}\text { School } \\
\text { expenditure }\end{array}$ & $\begin{array}{l}.071 \\
(.281)\end{array}$ & $\begin{array}{l}-.047 \\
(.184\end{array}$ & $\begin{array}{l}-.193 \\
(.196)\end{array}$ & $\begin{array}{l}.255 \\
(.300)\end{array}$ & $\begin{array}{l}.077 \\
(.183)\end{array}$ & $\begin{array}{l}.114 \\
(.223)\end{array}$ \\
\hline Income per capita & $\begin{array}{l}.103 \\
(.226)\end{array}$ & $\begin{array}{l}.137 \\
(.142\end{array}$ & $\begin{array}{l}.101 \\
(.193)\end{array}$ & $\begin{array}{l}-.025 \\
(.246)\end{array}$ & $\begin{array}{l}.013 \\
(.147)\end{array}$ & $\begin{array}{l}-.036 \\
(.199)\end{array}$ \\
\hline $\begin{array}{l}\text { Average years of } \\
\text { Education }\end{array}$ & $\begin{array}{l}-.003 \\
(.024)\end{array}$ & $\begin{array}{l}-.035 \\
(.024\end{array}$ & $\begin{array}{l}-.030 \\
(.029)\end{array}$ & $\begin{array}{l}.011 \\
(.044)\end{array}$ & $\begin{array}{l}-.037 \\
(.034)\end{array}$ & $\begin{array}{l}-.030 \\
(.055)\end{array}$ \\
\hline Observations & 20 & 20 & 20 & 20 & 20 & 20 \\
\hline R-squared & 0.118 & 0.423 & 0.229 & 0.083 & 0.556 & 0.266 \\
\hline
\end{tabular}


Table 10 - Teaching practices and Organization of firms

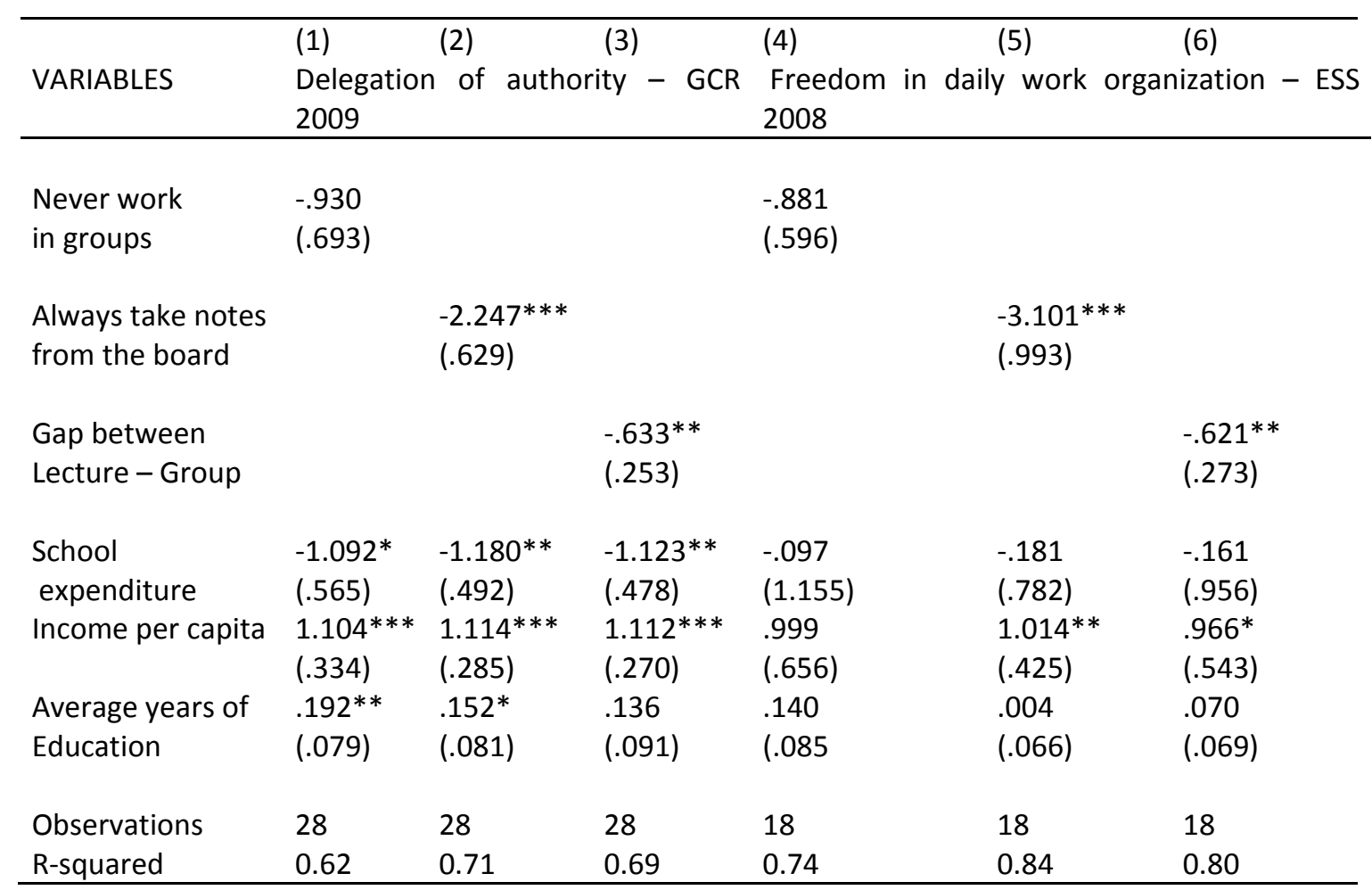


Table 10 (continued) - Teaching practices and Organization of firms

\begin{tabular}{|c|c|c|c|}
\hline \multirow[b]{2}{*}{ VARIABLES } & (7) & (8) & (9) \\
\hline & \multicolumn{3}{|c|}{$\begin{array}{l}\text { Quality of labor relations - } \\
\text { GCR } 2009\end{array}$} \\
\hline $\begin{array}{l}\text { Never work } \\
\text { in group }\end{array}$ & $\begin{array}{l}-1.394^{*} \\
(.812)\end{array}$ & & \\
\hline $\begin{array}{l}\text { Always take notes } \\
\text { from the board }\end{array}$ & & $\begin{array}{l}-2.094^{*} \\
(1.040)\end{array}$ & \\
\hline $\begin{array}{l}\text { Gap between } \\
\text { Lecture - Group }\end{array}$ & & & $\begin{array}{l}-.665^{* *} \\
(.274)\end{array}$ \\
\hline $\begin{array}{l}\text { School } \\
\text { expenditure }\end{array}$ & $\begin{array}{l}-.853^{*} \\
(.460)\end{array}$ & $\begin{array}{l}-.995^{*} \\
(.496)\end{array}$ & $\begin{array}{l}-.908^{*} \\
(.451)\end{array}$ \\
\hline Income per capita & $\begin{array}{l}.868^{* * *} \\
(.282)\end{array}$ & $\begin{array}{l}.895^{* *} \\
(.325)\end{array}$ & $\begin{array}{l}.869 * * * \\
(.284)\end{array}$ \\
\hline $\begin{array}{l}\text { Average years of } \\
\text { Education }\end{array}$ & $\begin{array}{l}.128^{*} \\
(.074)\end{array}$ & $\begin{array}{l}.100 \\
(.079)\end{array}$ & $\begin{array}{l}.080 \\
(.083)\end{array}$ \\
\hline Observations & 30 & 30 & 30 \\
\hline R-squared & 0.482 & 0.541 & 0.582 \\
\hline
\end{tabular}


Table 11 -Teaching practices and Institutions

\begin{tabular}{|c|c|c|c|c|c|c|}
\hline \multirow[b]{2}{*}{ VARIABLES } & (1) & (2) & (3) & (4) & (5) & (6) \\
\hline & \multicolumn{3}{|c|}{ Government accountability } & \multicolumn{3}{|c|}{ Regulation of entry } \\
\hline $\begin{array}{l}\text { Never work } \\
\text { in groups }\end{array}$ & $\begin{array}{l}-.193 \\
(.405)\end{array}$ & & & $\begin{array}{l}.457 \\
(.526)\end{array}$ & & \\
\hline $\begin{array}{l}\text { Always take notes } \\
\text { from the board }\end{array}$ & & $\begin{array}{l}-1.293^{* * *} \\
(.317)\end{array}$ & & & $\begin{array}{l}.843^{* *} \\
(.371)\end{array}$ & \\
\hline $\begin{array}{l}\text { Gap between } \\
\text { Lecture - Group }\end{array}$ & & & $\begin{array}{l}-.303^{* *} \\
(.146)\end{array}$ & & & $\begin{array}{l}.207 \\
(.155)\end{array}$ \\
\hline School expenditure & $\begin{array}{l}.023 \\
(.314)\end{array}$ & $\begin{array}{l}.026 \\
(.229)\end{array}$ & $\begin{array}{l}.045 \\
(.262)\end{array}$ & $\begin{array}{l}.010 \\
(.237)\end{array}$ & $\begin{array}{l}.065 \\
(.180)\end{array}$ & $\begin{array}{l}.040 \\
(.204)\end{array}$ \\
\hline Income per capita & $\begin{array}{l}.666^{* * *} \\
(.191)\end{array}$ & $\begin{array}{l}.645^{* * *} \\
(.130)\end{array}$ & $\begin{array}{l}.649 * * * \\
(.157)\end{array}$ & $\begin{array}{l}-.074 \\
(.189)\end{array}$ & $\begin{array}{l}-.094 \\
(.152)\end{array}$ & $\begin{array}{l}-.086 \\
(.170)\end{array}$ \\
\hline $\begin{array}{l}\text { Average years of } \\
\text { Education }\end{array}$ & $\begin{array}{l}.001 \\
(.039)\end{array}$ & $\begin{array}{l}-.029 \\
(.039)\end{array}$ & $\begin{array}{l}-.029 \\
(.048)\end{array}$ & $\begin{array}{l}-.125^{* * *} \\
(.028)\end{array}$ & $\begin{array}{l}-.108 * * * \\
(.031)\end{array}$ & $\begin{array}{l}-.109 * * * \\
(.032)\end{array}$ \\
\hline Observations & 30 & 30 & 30 & 30 & 30 & 30 \\
\hline R-squared & 0.851 & 0.900 & 0.870 & 0.378 & 0.418 & 0.385 \\
\hline
\end{tabular}


Table 12 -Teaching practices and Corruption

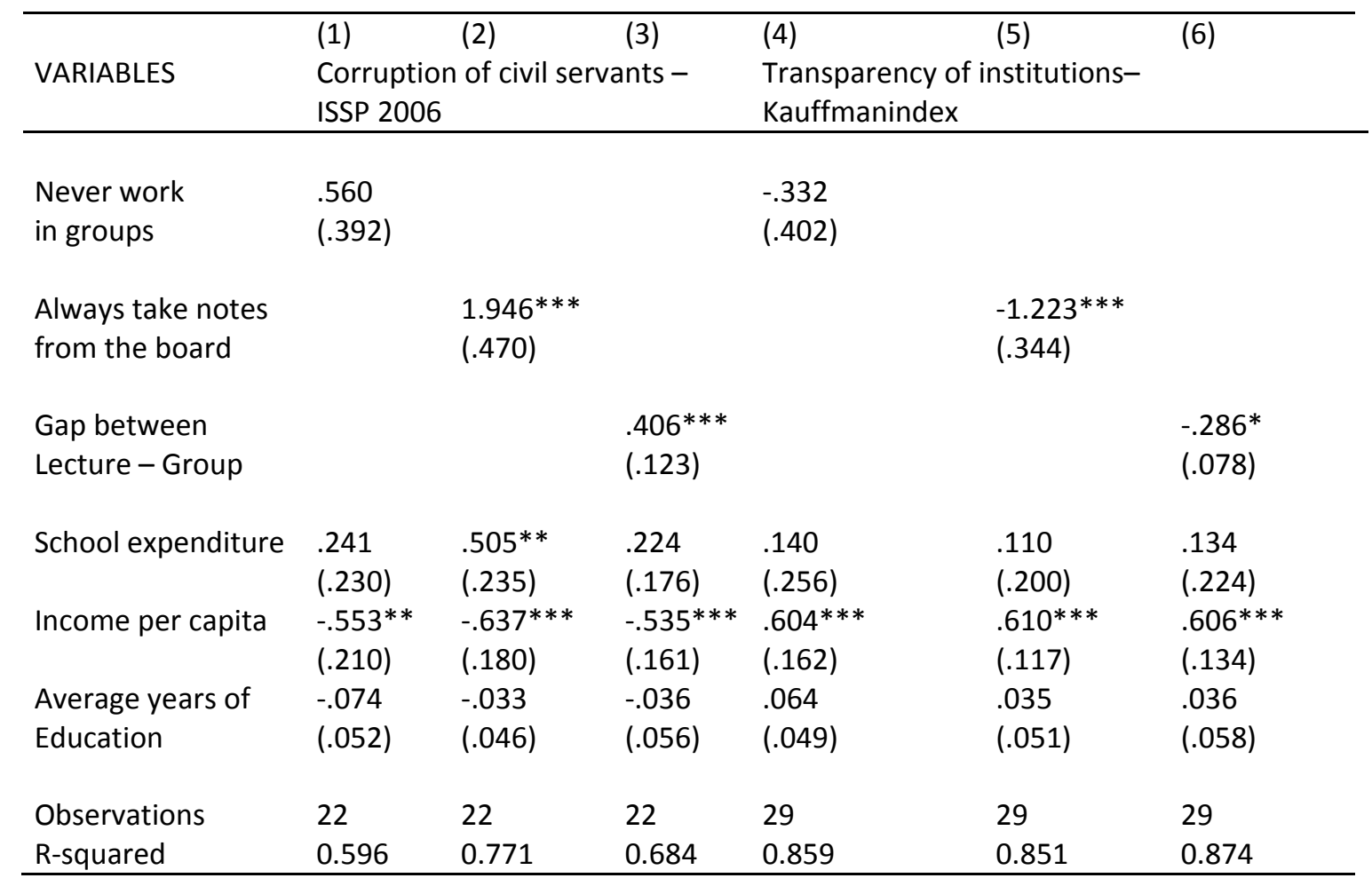


Table 13 - Cooperation among students and with teachers

\begin{tabular}{|c|c|c|c|c|c|c|}
\hline \multirow[b]{2}{*}{ VARIABLES } & (1) & (2) & (3) & (4) & (5) & (6) \\
\hline & \multicolumn{3}{|c|}{ Generalized Trust - WVS } & \multicolumn{3}{|c|}{ Association Memberships - WVS } \\
\hline Cooperation with teachers & & $\begin{array}{l}0.601^{* *} \\
(0.219)\end{array}$ & $\begin{array}{l}.595^{* *} \\
(.221)\end{array}$ & & $\begin{array}{l}.176 \\
(.407)\end{array}$ & \\
\hline Cooperation among students & $\begin{array}{l}.197^{*} \\
(.112)\end{array}$ & & & $\begin{array}{l}.437^{*} \\
(.216)\end{array}$ & & $\begin{array}{l}.628^{* *} \\
(.287)\end{array}$ \\
\hline School expenditure & $\begin{array}{l}-.277^{* *} \\
(.107)\end{array}$ & $\begin{array}{l}-.239 * * * \\
(.071)\end{array}$ & $\begin{array}{l}-.179 * * \\
(.077)\end{array}$ & $\begin{array}{l}-.092 \\
(.121)\end{array}$ & $\begin{array}{l}-.027 \\
(.142)\end{array}$ & $\begin{array}{l}-.219 \\
(.153)\end{array}$ \\
\hline Income per capita & $\begin{array}{l}.222^{* * *} \\
(.062)\end{array}$ & $\begin{array}{l}.197^{* * *} \\
(.047)\end{array}$ & $\begin{array}{l}.145^{* *} \\
(.052)\end{array}$ & $\begin{array}{l}.128 \\
(.081)\end{array}$ & $\begin{array}{l}.091 \\
(.095)\end{array}$ & $\begin{array}{l}.213^{*} \\
(.106)\end{array}$ \\
\hline Average years of education & $\begin{array}{l}.032^{* * *} \\
(.010)\end{array}$ & $\begin{array}{l}.030 \\
(.011)\end{array}$ & $\begin{array}{l}.010 \\
(.017)\end{array}$ & $\begin{array}{l}.066^{* * *} \\
(.012)\end{array}$ & $\begin{array}{l}.067^{* * *} \\
(.013)\end{array}$ & $\begin{array}{l}.044^{* *} \\
(.020)\end{array}$ \\
\hline Hierarchical religion & & & $\begin{array}{l}-.062 \\
(.065)\end{array}$ & & & $\begin{array}{l}.026 \\
(.116)\end{array}$ \\
\hline Common Law & & & $\begin{array}{l}.017 \\
(.059)\end{array}$ & & & $\begin{array}{l}-.068 \\
(.102)\end{array}$ \\
\hline German Law & & & $\begin{array}{l}.027 \\
(.057)\end{array}$ & & & $\begin{array}{l}.137^{*} \\
(.068)\end{array}$ \\
\hline Scandinavian Law & & & $\begin{array}{l}.153^{*} \\
(.076\end{array}$ & & & $\begin{array}{l}.201 \\
(.139)\end{array}$ \\
\hline Observations & 30 & 30 & 30 & 26 & 26 & 26 \\
\hline R-squared & 0.550 & 0.614 & 0.761 & 0.658 & 0.597 & 0.801 \\
\hline
\end{tabular}


Table 14 - Cognitive Skills and Teaching practices. Micro estimates: Source TIMSS

\begin{tabular}{|c|c|c|c|c|}
\hline \multirow[b]{2}{*}{ VARIABLES } & (1) & $(2)$ & (3) & (4) \\
\hline & \multicolumn{4}{|c|}{ Cognitive Test Scores } \\
\hline \multicolumn{5}{|l|}{ Teaching practices } \\
\hline Students take note from the board & $\begin{array}{l}-7.140^{* * *} \\
(1.034)\end{array}$ & & & \\
\hline Students work in groups & & $\begin{array}{c}-5.774^{* * *} \\
(1.076)\end{array}$ & & \\
\hline Take notes - Never & & & Reference & \\
\hline Take notes - Sometime & & & $\begin{array}{c}1.344 \\
(3.717)\end{array}$ & \\
\hline Take notes - Often & & & $\begin{array}{c}-10.98^{* * *} \\
(4.006)\end{array}$ & \\
\hline Take notes - Always & & & $\begin{array}{c}-15.84^{* * *} \\
(4.332)\end{array}$ & \\
\hline Work in groups - Never & & & & Reference \\
\hline Work in groups - Sometime & & & & $\begin{array}{c}7.883^{* * *} \\
(1.888)\end{array}$ \\
\hline Work in groups - Often & & & & $\begin{array}{l}-1.313 \\
(3.073)\end{array}$ \\
\hline Work in groups - Always & & & & $\begin{array}{c}-23.82 * * * \\
(3.066)\end{array}$ \\
\hline \multicolumn{5}{|l|}{ Student Characteristics } \\
\hline Girl & $\begin{array}{c}-5.064^{* * *} \\
(1.423)\end{array}$ & $\begin{array}{c}-4.879 * * * \\
(1.421)\end{array}$ & $\begin{array}{c}-5.160^{* * *} \\
(1.417)\end{array}$ & $\begin{array}{c}-5.359^{* * *} \\
(1.394)\end{array}$ \\
\hline Age & $\begin{array}{c}3.415^{* * *} \\
(0.978)\end{array}$ & $\begin{array}{c}3.544^{* * *} \\
(0.966)\end{array}$ & $\begin{array}{c}3.493^{* * *} \\
(0.978)\end{array}$ & $\begin{array}{c}3.421^{* * *} \\
(0.950)\end{array}$ \\
\hline Born abroad & $\begin{array}{l}-11.97^{* * *} \\
(3.156)\end{array}$ & $\begin{array}{c}-11.69^{* * *} \\
(3.095)\end{array}$ & $\begin{array}{c}-11.86^{* * *} \\
(3.149)\end{array}$ & $\begin{array}{c}-11.20^{* * *} \\
(3.006)\end{array}$ \\
\hline Number of books at home & $\begin{array}{c}14.71^{* * *} \\
(0.636)\end{array}$ & $\begin{array}{c}14.66^{* * *} \\
(0.632)\end{array}$ & $\begin{array}{c}14.68^{* * *} \\
(0.637)\end{array}$ & $\begin{array}{c}14.61^{* * *} \\
(0.626)\end{array}$ \\
\hline Mother's education & $\begin{array}{c}4.680^{* * *} \\
(0.510)\end{array}$ & $\begin{array}{c}4.863^{* * *} \\
(0.520)\end{array}$ & $\begin{array}{l}4.667^{* * *} \\
(0.509)\end{array}$ & $\begin{array}{c}4.829^{* * *} \\
(0.504)\end{array}$ \\
\hline Father's education & $\begin{array}{c}5.656^{* * *} \\
(0.570)\end{array}$ & $\begin{array}{c}5.447^{* * *} \\
(0.566)\end{array}$ & $\begin{array}{c}5.638^{* * *} \\
(0.570)\end{array}$ & $\begin{array}{c}5.493^{* * *} \\
(0.568)\end{array}$ \\
\hline \multicolumn{5}{|l|}{$\begin{array}{l}\text { Teacher and School } \\
\text { Characteristics }\end{array}$} \\
\hline Teacher's age & $\begin{array}{c}2.658 \\
(3.143)\end{array}$ & $\begin{array}{c}2.894 \\
(3.183)\end{array}$ & $\begin{array}{c}2.640 \\
(3.135)\end{array}$ & $\begin{array}{c}3.005 \\
(3.167)\end{array}$ \\
\hline Teacher's gender (female) & $\begin{array}{l}8.814^{* *} \\
(4.129)\end{array}$ & $\begin{array}{l}8.975^{* *} \\
(4.019)\end{array}$ & $\begin{array}{l}8.858^{* *} \\
(4.128)\end{array}$ & $\begin{array}{l}8.624^{* *} \\
(3.874)\end{array}$ \\
\hline Teacher's education & $\begin{array}{l}6.160^{* * *} \\
(2.026)\end{array}$ & $\begin{array}{c}6.542^{* * *} \\
(1.900)\end{array}$ & $\begin{array}{l}6.129 * * * \\
(2.024)\end{array}$ & $\begin{array}{c}6.898^{* * *} \\
(1.819)\end{array}$ \\
\hline Teacher's experience & $\begin{array}{c}0.222 \\
(0.309)\end{array}$ & $\begin{array}{c}0.228 \\
(0.308)\end{array}$ & $\begin{array}{c}0.229 \\
(0.311)\end{array}$ & $\begin{array}{c}0.241 \\
(0.306)\end{array}$ \\
\hline Class size (ln) & $\begin{array}{c}3.958 \\
(6.725)\end{array}$ & $\begin{array}{c}5.191 \\
(6.198)\end{array}$ & $\begin{array}{l}4.090 \\
(6.800)\end{array}$ & $\begin{array}{l}5.580 \\
(6.067)\end{array}$ \\
\hline Shortage of instruction materials & $\begin{array}{l}-3.418^{*} \\
(1.777)\end{array}$ & $\begin{array}{c}-3.488^{* *} \\
(1.690)\end{array}$ & $\begin{array}{l}-3.438^{*} \\
(1.780)\end{array}$ & $\begin{array}{c}-3.399 * * \\
(1.623)\end{array}$ \\
\hline Urban area & $\begin{array}{c}5.376^{* * *} \\
(1.724)\end{array}$ & $\begin{array}{c}4.582^{* * *} \\
(1.716)\end{array}$ & $\begin{array}{c}5.380^{* * *} \\
(1.731)\end{array}$ & $\begin{array}{c}4.959^{* * *} \\
(1.671)\end{array}$ \\
\hline Observations & 108506 & 108506 & 108506 & 108506 \\
\hline R-squared & 0.274 & 0.271 & 0.275 & 0.278 \\
\hline
\end{tabular}


Table 15 - Cognitive skills and Average years of education. Macro estimates

\begin{tabular}{|c|c|c|c|c|c|c|}
\hline \multirow{2}{*}{$\begin{array}{l}\text { VARIABLES } \\
\begin{array}{l}\text { Never work } \\
\text { in groups }\end{array}\end{array}$} & \multicolumn{3}{|c|}{$\begin{array}{l}\text { Cognitive skills in grade } 8^{\text {th }}- \\
\text { TIMSS } 1995\end{array}$} & \multicolumn{3}{|c|}{ Average years of education } \\
\hline & $\begin{array}{l}.741 \\
(.120)\end{array}$ & & & $\begin{array}{l}-1.253 \\
(1.756)\end{array}$ & & \\
\hline $\begin{array}{l}\text { Always take notes } \\
\text { from the board }\end{array}$ & & $\begin{array}{l}1.387 \\
(1.187)\end{array}$ & & & $\begin{array}{l}-4.133^{*} \\
(1.760)\end{array}$ & \\
\hline $\begin{array}{l}\text { Gap between } \\
\text { Lecture and Group }\end{array}$ & & & $\begin{array}{l}.326 \\
(.224)\end{array}$ & & & $\begin{array}{l}-1.271^{* * *} \\
(.406)\end{array}$ \\
\hline $\begin{array}{l}\text { School } \\
\text { Expenditure } \\
\text { Income per capita }\end{array}$ & $\begin{array}{l}.533 \\
(.376) \\
-.311 \\
(.254)\end{array}$ & $\begin{array}{l}.510 \\
(.302) \\
-.278 \\
(.220)\end{array}$ & $\begin{array}{l}.534 \\
(.328) \\
-.109 \\
(.035)\end{array}$ & $\begin{array}{l}1.907 \\
(1.400) \\
-.523 \\
(.930)\end{array}$ & $\begin{array}{l}.889 \\
(.544) \\
-.748 \\
(.797)\end{array}$ & $\begin{array}{l}1.963 \\
(1.262) \\
-.706 \\
(.828)\end{array}$ \\
\hline $\begin{array}{l}\text { Observations } \\
\text { R-squared }\end{array}$ & $\begin{array}{l}28 \\
0.068 \\
\end{array}$ & $\begin{array}{l}28 \\
0.102 \\
\end{array}$ & $\begin{array}{l}28 \\
0.088 \\
\end{array}$ & $\begin{array}{l}30 \\
0.281 \\
\end{array}$ & $\begin{array}{l}30 \\
0.557 \\
\end{array}$ & $\begin{array}{l}30 \\
0.372 \\
\end{array}$ \\
\hline
\end{tabular}

Table 16 - Share of repeaters and Socioeconomic inequality. Macro estimates

\begin{tabular}{|c|c|c|c|c|c|c|}
\hline \multirow[b]{2}{*}{ VARIABLES } & (1) & (2) & (3) & & (5) & (6) \\
\hline & \multicolumn{3}{|c|}{ Share of repeaters } & \multicolumn{3}{|c|}{$\begin{array}{l}\text { Index of socio-economic inequality } \\
\text { cognitive scores }\end{array}$} \\
\hline $\begin{array}{l}\text { Never work } \\
\text { in groups }\end{array}$ & $\begin{array}{l}.177 \\
(.142)\end{array}$ & & & $\begin{array}{l}.254 \\
(.200)\end{array}$ & & \\
\hline $\begin{array}{l}\text { Always take notes } \\
\text { from the board }\end{array}$ & & $\begin{array}{l}.324 * * \\
(.148)\end{array}$ & & & $\begin{array}{l}.573^{* * *} \\
(.200)\end{array}$ & \\
\hline $\begin{array}{l}\text { Gap between } \\
\text { Lecture and Group }\end{array}$ & & & $\begin{array}{l}.084^{*} \\
(.044)\end{array}$ & & & $\begin{array}{l}.128^{* *} \\
(.058)\end{array}$ \\
\hline $\begin{array}{l}\text { School } \\
\text { Expenditure } \\
\text { Income per capita }\end{array}$ & $\begin{array}{l}.099 \\
(.072) \\
-.051 \\
(.047)\end{array}$ & $\begin{array}{l}.096 \\
(.065) \\
-.032 \\
(.037)\end{array}$ & $\begin{array}{l}.102 \\
(.065) \\
-.042 \\
(.040)\end{array}$ & $\begin{array}{l}-.115 \\
(.125) \\
-.115 \\
(.125)\end{array}$ & $\begin{array}{l}.183 \\
(.140) \\
-.079 \\
(.115)\end{array}$ & $\begin{array}{l}.196 \\
(.147) \\
-.100 \\
(.122)\end{array}$ \\
\hline $\begin{array}{l}\text { Observations } \\
\text { R-squared }\end{array}$ & $\begin{array}{l}28 \\
0.197\end{array}$ & $\begin{array}{l}28 \\
0.293\end{array}$ & $\begin{array}{l}28 \\
0.274\end{array}$ & $\begin{array}{l}28 \\
0.138\end{array}$ & $\begin{array}{l}28 \\
0.247\end{array}$ & $\begin{array}{l}28 \\
0.194\end{array}$ \\
\hline
\end{tabular}


Table R1 - Immigrant's Belief in Cooperation: Micro estimates. Source: CES

\begin{tabular}{|c|c|c|c|c|}
\hline \multirow{2}{*}{ VARIABLES } & (1) & (2) & (3) & (4) \\
\hline & \multicolumn{2}{|c|}{$\begin{array}{c}\text { Belief in cooperation between } \\
\text { students and teachers }\end{array}$} & \multicolumn{2}{|c|}{$\begin{array}{c}\text { Belief in cooperation among } \\
\text { among students }\end{array}$} \\
\hline \multicolumn{5}{|l|}{ Teaching practices } \\
\hline \multirow[t]{2}{*}{ Horizontal teaching } & 0.0528 & & $0.0607 * * *$ & \\
\hline & $(0.0358)$ & & $(0.0232)$ & \\
\hline \multirow[t]{2}{*}{ Vertical teaching } & & $-0.119 * * *$ & & -0.0471 \\
\hline & & $(0.0418)$ & & $(0.0287)$ \\
\hline \multicolumn{5}{|l|}{ Student characteristics } \\
\hline \multirow[t]{2}{*}{ Female } & $0.387 * * *$ & $0.387^{* * *}$ & $0.155^{* * *}$ & $0.160 * * *$ \\
\hline & $(0.0720)$ & $(0.0730)$ & $(0.0563)$ & $(0.0564)$ \\
\hline \multirow[t]{2}{*}{ Father's education } & 0.0182 & 0.0155 & 0.0329 & 0.0282 \\
\hline & $(0.0287)$ & $(0.0284)$ & $(0.0253)$ & $(0.0250)$ \\
\hline \multirow[t]{2}{*}{ Mother's education } & 0.0127 & 0.0116 & -0.0145 & -0.00950 \\
\hline & $(0.0322)$ & $(0.0324)$ & $(0.0233)$ & $(0.0231)$ \\
\hline \multirow[t]{2}{*}{ Number of books at home } & 0.0219 & 0.0262 & -0.0262 & -0.0215 \\
\hline & $(0.0321)$ & $(0.0314)$ & $(0.0255)$ & $(0.0254)$ \\
\hline \multirow[t]{2}{*}{ Grade } & 0.411 & 0.321 & -0.166 & 0.253 \\
\hline & $(0.362)$ & $(0.361)$ & $(0.344)$ & $(0.194)$ \\
\hline \multirow[t]{2}{*}{ Age } & 0.0591 & 0.0513 & 0.00930 & 0.0105 \\
\hline & (0.0393) & $(0.0392)$ & (0.0299) & $(0.0300)$ \\
\hline \multicolumn{5}{|l|}{ Teacher and School characteristics } \\
\hline \multirow[t]{2}{*}{ Teacher 's education } & $-0.0956^{*}$ & $-0.102 *$ & -0.00823 & 0.00282 \\
\hline & $(0.0536)$ & $(0.0532)$ & $(0.0517)$ & $(0.0504)$ \\
\hline \multirow[t]{2}{*}{ Teacher 'experience } & 0.00241 & 0.00237 & 0.00177 & 0.00126 \\
\hline & $(0.0107)$ & $(0.0101)$ & (0.00729) & $(0.00763)$ \\
\hline \multirow[t]{2}{*}{ Teacher' sage } & 0.0582 & 0.0494 & 0.00447 & 0.00490 \\
\hline & $(0.105)$ & $(0.0992)$ & $(0.0744)$ & $(0.0773)$ \\
\hline \multirow[t]{2}{*}{ Teacher 's gender (female) } & 0.0134 & 0.0666 & 0.0860 & 0.137 \\
\hline & $(0.134)$ & $(0.130)$ & $(0.102)$ & $(0.101)$ \\
\hline \multirow[t]{2}{*}{ Teacher 's trust } & -0.0336 & -0.0291 & -0.0246 & -0.0137 \\
\hline & $(0.0289)$ & $(0.0282)$ & $(0.0211)$ & $(0.0207)$ \\
\hline \multirow[t]{2}{*}{ Teacher' s activities } & 0.0447 & 0.0468 & $0.0703 * *$ & 0.0524 \\
\hline & $(0.0486)$ & $(0.0446)$ & $(0.0337)$ & $(0.0332)$ \\
\hline \multirow[t]{2}{*}{ Teacher 's belief in cooperation } & 0.0606 & 0.0661 & -0.0274 & -0.00874 \\
\hline & $(0.0448)$ & $(0.0416)$ & $(0.0339)$ & $(0.0334)$ \\
\hline \multirow[t]{2}{*}{ Class size $(\ln )$} & $-0.402^{*}$ & -0.358 & 0.0278 & 0.0421 \\
\hline & $(0.224)$ & $(0.224)$ & (0.193) & $(0.200)$ \\
\hline \multirow[t]{2}{*}{ Public school } & -0.0112 & -0.0129 & 0.130 & 0.139 \\
\hline & $(0.144)$ & $(0.147)$ & $(0.0907)$ & $(0.0894)$ \\
\hline Number of students from & -0.00208 & -0.00248 & -0.00168 & -0.00159 \\
\hline low socio-eco backgrounds & $(0.00186)$ & $(0.00178)$ & $(0.00131)$ & $(0.00131)$ \\
\hline Country fixed effects & Yes*** & Yes*** & Yes*** & Yes*** \\
\hline Observations & 1742 & 1742 & 1742 & 1742 \\
\hline R-squared & 0.075 & 0.083 & 0.051 & 0.050 \\
\hline
\end{tabular}


Table R2 - Immigrants' Trust and Association membership: Micro estimates. Source : CES

\begin{tabular}{|c|c|c|c|c|}
\hline & (1) & $(2)$ & (3) & (4) \\
\hline VARIABLES & \multicolumn{2}{|c|}{ Trust } & \multicolumn{2}{|c|}{ Association membership } \\
\hline \multicolumn{5}{|l|}{ Teaching practices } \\
\hline \multirow[t]{2}{*}{ Horizontal teaching } & $0.113^{* * *}$ & & 0.0520 & \\
\hline & $(0.0304)$ & & $(0.0427)$ & \\
\hline \multirow[t]{2}{*}{ Vertical teaching } & & 0.0185 & & -0.0520 \\
\hline & & $(0.0377)$ & & $(0.0477)$ \\
\hline \multicolumn{5}{|l|}{ Student characteristics } \\
\hline \multirow[t]{2}{*}{ Female } & 0.0912 & 0.0872 & -0.0980 & -0.111 \\
\hline & $(0.0715)$ & $(0.0728)$ & $(0.0984)$ & $(0.0988)$ \\
\hline \multirow[t]{2}{*}{ Father's education } & -0.00354 & 0.000439 & -0.00855 & -0.00898 \\
\hline & $(0.0291)$ & $(0.0289)$ & $(0.0392)$ & (0.0389) \\
\hline \multirow[t]{2}{*}{ Mother's education } & $-0.0538^{*}$ & $-0.0563^{*}$ & -0.00773 & -0.00981 \\
\hline & $(0.0301)$ & $(0.0302)$ & $(0.0418)$ & $(0.0417)$ \\
\hline \multirow[t]{2}{*}{ Number of books at home } & 0.0179 & 0.0218 & $0.199 * * *$ & $0.197 * * *$ \\
\hline & $(0.0322)$ & $(0.0326)$ & $(0.0437)$ & $(0.0433)$ \\
\hline \multirow[t]{2}{*}{ Grade } & -0.701 & -0.253 & 0.233 & 0.220 \\
\hline & $(0.567)$ & $(0.202)$ & $(1.144)$ & (1.149) \\
\hline \multirow[t]{2}{*}{ Age } & 0.0444 & 0.0395 & 0.0290 & 0.0294 \\
\hline & $(0.0387)$ & $(0.0392)$ & $(0.0614)$ & $(0.0610)$ \\
\hline \multicolumn{5}{|l|}{ Teacher and school Characteristics } \\
\hline \multirow[t]{2}{*}{ Teacher's education } & -0.0592 & -0.0448 & -0.0229 & -0.0200 \\
\hline & $(0.0566)$ & $(0.0564)$ & $(0.0740)$ & $(0.0725)$ \\
\hline \multirow[t]{2}{*}{ Teacher's experience } & -0.00382 & 0.00311 & 0.00133 & 0.00736 \\
\hline & $(0.00973)$ & $(0.00991)$ & $(0.0128)$ & $(0.0131)$ \\
\hline \multirow{2}{*}{ Teacher's age } & 0.0443 & -0.0158 & 0.0327 & -0.0190 \\
\hline & $(0.0967)$ & $(0.0998)$ & $(0.126)$ & $(0.126)$ \\
\hline \multirow[t]{2}{*}{ Teacher's gender (female) } & -0.143 & -0.0578 & -0.0924 & -0.0536 \\
\hline & $(0.112)$ & $(0.111)$ & $(0.163)$ & $(0.160)$ \\
\hline \multirow[t]{2}{*}{ Teacher's trust } & 0.000991 & 0.0187 & -0.0340 & -0.0280 \\
\hline & $(0.0244)$ & $(0.0243)$ & $(0.0375)$ & $(0.0370)$ \\
\hline \multirow[t]{2}{*}{ Teacher ' civic attitudes } & $0.0994^{* *}$ & 0.0605 & 0.0143 & -0.0101 \\
\hline & $(0.0461)$ & $(0.0462)$ & $(0.0521)$ & $(0.0531)$ \\
\hline \multirow[t]{2}{*}{ Teacher 's belief in cooperation } & -0.00842 & 0.0366 & 0.0411 & 0.0635 \\
\hline & $(0.0426)$ & $(0.0407)$ & $(0.0570)$ & $(0.0554)$ \\
\hline \multirow[t]{2}{*}{ Class size (In) } & -0.0671 & -0.0823 & $-0.806 * *$ & $-0.847 * *$ \\
\hline & $(0.248)$ & $(0.269)$ & $(0.335)$ & $(0.337)$ \\
\hline \multirow[t]{2}{*}{ Public school } & -0.0269 & -0.00985 & 0.172 & 0.169 \\
\hline & $(0.112)$ & $(0.114)$ & $(0.146)$ & $(0.146)$ \\
\hline Number of students from & 0.00145 & 0.00156 & 0.00124 & 0.000959 \\
\hline low socio-eco backgrounds & $(0.00161)$ & $(0.00170)$ & $(0.00221)$ & $(0.00217)$ \\
\hline Country fixed effects & Yes $* * *$ & Yes $* * *$ & Yes $* * *$ & Yes $* * *$ \\
\hline Observations & 1652 & 1652 & 1652 & 1652 \\
\hline R-squared & 0.046 & 0.037 & 0.119 & 0.119 \\
\hline
\end{tabular}




\section{Appendix 2 - Descriptive statistics}

Table A1- Definition and descriptive statistics for the database "Civic Education Study".

\begin{tabular}{|c|c|c|}
\hline Variable definitions- Teacher characteristics & Mean & $\begin{array}{l}\text { Standard } \\
\text { deviation }\end{array}$ \\
\hline $\begin{array}{l}\text { "Teacher lectures": This variable derives from question: "In your class, how often does } \\
\text { the teacher lecture?" The answer equals } 1 \text { for "Never", } 2 \text { for "Sometimes", } 3 \text { for } \\
\text { "Often" and } 4 \text { for "Very often". Source: Teacher survey }\end{array}$ & 2.338 & .868 \\
\hline $\begin{array}{l}\text { "Teacher asks questions": This variable derives from the question: "In your class, how } \\
\text { often does the teacher asks questions to the students?" The answer equals } 1 \text { for } \\
\text { "Never", } 2 \text { for "Sometimes", } 3 \text { for "Often" and } 4 \text { for "Very often". Source: Teacher } \\
\text { survey }\end{array}$ & 3.056 & .754 \\
\hline $\begin{array}{l}\text { "Students work in groups": This variable derives from the question: "In your class, how } \\
\text { often do the students work in groups?" The answer equals } 1 \text { for "Never", } 2 \text { for } \\
\text { "Sometimes", } 3 \text { for "Often" and } 4 \text { for "Very often".Source: Teacher survey }\end{array}$ & 2.557 & .787 \\
\hline $\begin{array}{l}\text { "Students work on projects": This variable derives from the question reads: "In your } \\
\text { class, how often do the students work on projects?" The answer equals } 1 \text { for "Never", } 2 \\
\text { for "Sometimes", } 3 \text { for "Often" and } 4 \text { for "Very often".Source: Teacher survey }\end{array}$ & 2.389 & .729 \\
\hline $\begin{array}{l}\text { "Students work on textbook": This variable derives from the question reads: "In your } \\
\text { class, how often do the students study textbooks?" The answer equals } 1 \text { for "Never", } 2 \\
\text { for "Sometimes", } 3 \text { for "Often" and } 4 \text { for "Very often".Source: Teacher survey }\end{array}$ & 2.990 & .856 \\
\hline $\begin{array}{l}\text { "Students participate in events": This variable derives from the question: "In your class, } \\
\text { how often do the students participate in events?" The answer equals } 1 \text { for "Never", } 2 \\
\text { for "Sometimes", } 3 \text { for "Often" and } 4 \text { for "Very often".Source: Teacher survey }\end{array}$ & 2.199 & .760 \\
\hline $\begin{array}{l}\text { "Students participate in role play": This variable derives from the question: "In your } \\
\text { class, how often do the students participate in role plays?" The answer equals } 1 \text { for } \\
\text { "Never", } 2 \text { for "Sometimes", } 3 \text { for "Often" and } 4 \text { for "Very often". }\end{array}$ & 2.148 & .815 \\
\hline $\begin{array}{l}\text { "Discussion between teacher and students": This variable derives from the question: "In } \\
\text { your class, how often does the teacher includes discussion. The answer equals } 1 \text { for } \\
\text { "Never", } 2 \text { for "Sometimes", } 3 \text { for "Often" and } 4 \text { for "Very often". }\end{array}$ & 2.798 & .742 \\
\hline $\begin{array}{l}\text { "Horizontal teaching": This variable is the first principal component of the variables } \\
\text { "Students work in groups", "Discussion between teacher and students", " Students } \\
\text { work on projects", "Students organize events", "Students participate in role plays". }\end{array}$ & .380 & 1.603 \\
\hline $\begin{array}{l}\text { "Vertical teaching": This variable is the first principal component of the variables } \\
\text { "Teacher lectures", "Teacher asks questions", "Students work on textbook". }\end{array}$ & .017 & 1.320 \\
\hline
\end{tabular}


Table A1 (Continued)

\begin{tabular}{|c|c|c|}
\hline Variable definitions - Teacher and School characteristics & Mean & $\begin{array}{l}\text { Standard } \\
\text { deviation }\end{array}$ \\
\hline $\begin{array}{l}\text { Teacher's age. Variable with six categories: } 1=\text { under } 25 \text { years old, } 2=25-29 \text { years old, } \\
3=30-39 \text { years old, } 4=40-49 \text { years old, } 5=50-59 \text { years old, } 6=60 \text { years old or more. } \\
\text { Source: Teacher survey }\end{array}$ & 3.667 & 1.109 \\
\hline $\begin{array}{l}\text { Teacher's education. This variable measures the highest level of former education, in } 5 \\
\text { categories. Source: Teacher survey }\end{array}$ & 3.076 & 1.235 \\
\hline Teacher's experience: number of years of teaching altogether. Source: Teacher survey & 16.712 & 10.599 \\
\hline $\begin{array}{l}\text { Teacher's gender: dummy variable equal } 1 \text { if female, and } 0 \text { for male. Source Teacher } \\
\text { survey }\end{array}$ & .668 & .470 \\
\hline $\begin{array}{l}\text { Teacher's civic attitudes: This variable is the first principal component of the questions } \\
\text { 1) "For being a good citizen, one has to vote on every election", 2) "For being a good } \\
\text { citizen, one has to join a political party", 3) "For being a good citizen, one has to read } \\
\text { about politics", 4) "For being a good citizen, one has to participate in social activities". } \\
\text { The answers equal from } 1 \text { for "Strongly disagree", } 2 \text { for "Disagree", } 3 \text { for "Agree" and } 4 \\
\text { for "Strongly agree". Source: Teacher survey }\end{array}$ & .002 & 1.312 \\
\hline $\begin{array}{l}\text { Teacher's trust: This variable is the principal first component of questions1)“How much } \\
\text { confidence do you have in the political system?",2) "How much confidence do you } \\
\text { have in elections?", 3) "How much confidence do you have in the judicial system?", 4) } \\
\text { "How much confidence do you have in immigration?", 5) "How much confidence do } \\
\text { you have in social welfare?", 6) "How much confidence do you have in labor unions?". } \\
\text { The answers equal } 1 \text { for "Not at all", } 2 \text { for "Little confidence", } 3 \text { for "Confident" and } 4 \\
\text { for "Very confident". Source: Teacher survey }\end{array}$ & .082 & 1.962 \\
\hline $\begin{array}{l}\text { Teacher's beliefs in cooperation: This variable is the first principal component of the } \\
\text { questions 1) "Students learn at school to understand people" and 2) "Students learn at } \\
\text { school is to cooperate in groups". The answers range from } 1 \text { for "Strongly disagree" to } \\
4 \text { for "Strongly agree". Source: Teacher survey. }\end{array}$ & .040 & 1.180 \\
\hline Size of the class: number of students per classroom. Source: School Survey & 25.66 & 6.48 \\
\hline
\end{tabular}


Table A1 (continued)

\begin{tabular}{|c|c|c|}
\hline Variables - Student characteristics & Means & $\begin{array}{l}\text { Standard } \\
\text { deviation }\end{array}$ \\
\hline Student age: number of years. Source: Student survey & 14.166 & .704 \\
\hline \multicolumn{3}{|l|}{ Student gender: dummy equal 1 if female, and 0 otherwise. Source: Student survey } \\
\hline $\begin{array}{l}\text { Immigrant: dummy variable equal } 1 \text { if the student is born abroad, } 0 \text { otherwise. Source: } \\
\text { Student survey }\end{array}$ & .066 & .247 \\
\hline Grade: variable equal 8 for the $8^{\text {th }}$ grade, and 9 for the $9^{\text {th }}$ grade. Source: student survey & 8.337 & .473 \\
\hline $\begin{array}{l}\text { Mother's education: This variable derives from the question "How far in school did your } \\
\text { mother go?" The answer equals } 1=\text { No elementary education, } 2=\text { Finish elementary school, } \\
\text { 3=Finish secondary elementary high school, } 4=\text { Finish high school, } 5=\text { Some higher technical } \\
\text { education, } 6=\text { Some college, university, } 7=\text { Higher education. Source: Student survey }\end{array}$ & 4.156 & 1.578 \\
\hline $\begin{array}{l}\text { Father's education: This variable derives from the question "How far in school did your } \\
\text { father go?" The answer equals } 1=\text { No elementary education, 2=Finish elementary school, } \\
\text { 3=Finish secondary elementary high school, 4= Finish high school, 5= Some higher technical } \\
\text { education, 6=Some college, university, 7=Higher education. Source: Student survey }\end{array}$ & 4.183 & 1.563 \\
\hline $\begin{array}{l}\text { Number of books at home: measured by the question "How many books are there in your } \\
\text { home?". The answer has } 7 \text { categories: } 1=\text { None, } 2=1-10 \text { books, } 3=11-50 \text { books, } 4=51-100 \\
\text { books, } 5=101-200 \text { books, } 6=\text { more than } 200 \text { books. Source: Student survey }\end{array}$ & 4.287 & 1.350 \\
\hline $\begin{array}{l}\text { "Student's belief in cooperation among students". This variable is the first principal } \\
\text { component of the questions: 1) "The goal of education is to understand people with } \\
\text { different ideas" and 2) "The goal of education is to learn how to cooperate in groups with } \\
\text { other students". The answers ranges from } 1 \text { for Strongly Disagree, } 2 \text { for Disagree, } 3 \text { for } \\
\text { Agree and } 4 \text { for Strongly Agree. Source: student survey }\end{array}$ & -.018 & 1.211 \\
\hline $\begin{array}{l}\text { "Student's belief in cooperation between students and teacher". This variable is the first } \\
\text { principal component of the questions: 1) "Are students encouraged to make up their own } \\
\text { opinion?", 2)“Do teacher respect your opinion?", 3)" Do you feel free to express opinions in } \\
\text { class?", 4)“Do you feel free to openly disagree with the teacher?". The answers range from } \\
1 \text { for strongly disagree to } 4 \text { for strongly agree. Source: student survey. }\end{array}$ & -.009 & 1.476 \\
\hline $\begin{array}{l}\text { "Student association membership". This variable is the first principal component of the } \\
\text { questions: "Have you ever participated to: A student council? A youth organization? A school } \\
\text { newspaper? An environmental organization? A U.N or UNESCO Club? A Student exchange } \\
\text { program? A Human Rights Organization? A Group Conducting Activities? A Charity } \\
\text { Collecting ? A boy or girl scout group? A cultural association? A computer club? An art, } \\
\text { drama or music association? A Sport Organization? An association supported by a religious } \\
\text { group?".. For each association, the answer equal } 1 \text { if the respondent participates to it and } 0 \\
\text { otherwise. Source: student survey. }\end{array}$ & .049 & 1.770 \\
\hline $\begin{array}{l}\text { "Student's level of trust". This variable is the first principal component of the questions "How } \\
\text { much confidence do you have in: 1) Justice? 2) The Police?,3) Education } \\
\text { institutions/Schools? , 4) The people who live in this country?". The answers equal } 1 \text { for "Not } \\
\text { at all", } 2 \text { for "Little confidence", } 3 \text { for "Confident" and } 4 \text { for "Very confident". Source: } \\
\text { Student survey }\end{array}$ & .028 & 1.755 \\
\hline
\end{tabular}

